Boise State University

ScholarWorks

Geosciences Faculty Publications and

Presentations

Department of Geosciences

$11-1-2010$

Rare Earth and High Field Strength Element Partitioning Between Iron-Rich Clinopyroxenes and Felsic Liquids

Paul H. Olin

Boise State University

John A. Wolff

Washington State University 


\title{
Rare Earth and High Field Strength Element Partitioning Between Iron-Rich Clinopyroxenes and Felsic Liquids
}

\author{
Paul H. Olin \\ Boise State University \\ J.A. Wolff \\ Washington State University
}

\begin{abstract}
Rare earth elements are commonly assumed to substitute only for $\mathrm{Ca}$ in clinopyroxene because of the similarity of ionic radii for $\mathrm{REE}^{3+}$ and $\mathrm{Ca}^{2+}$ in 8 -fold coordination. The assumption is valid for Mg-rich clinopyroxenes for which observed mineral $/ \mathrm{melt}$ partition coefficients are readily predicted by the lattice strain model for substitution onto a single site (e.g. Wood and Blundy, 1997). We show that natural Fe-rich pyroxenes in both silica-undersaturated and-oversaturated magmatic systems deviate from this behavior. Salites (Mg\# 48 to 59) in phonolites from Tenerife, ferrohedenbergites (Mg\# 14.2 to 16.2) from the rhyolitic Bandelier Tuff, and ferroaugites (Mg\# 9.6 to 32) from the rhyolitic Rattlesnake Tuff have higher heavy REE contents than predicted by single-site substitution. The ionic radius of $\mathrm{Fe}^{2+}$ in $6-$ fold coordination is substantially greater than that of $\mathrm{Mg}^{2+}$, hence we propose that, in Fe-rich clinopyroxenes, heavy REE are significantly partitioned between 8-fold Ca sites and 6-fold $\mathrm{Fe}-\mathrm{Mg}$ sites such that $\mathrm{Yb}$ and $\mathrm{Lu}$ exist dominantly in 6-fold coordination. We also outline a REE-based method of identifying pyroxene-melt pairs in systems with multiple liquid and crystal populations, based upon the assumption that LREE and MREE reside exclusively in 8-fold coordination in pyroxene.
\end{abstract}

Contrary to expectations, interpolation of mineral/melt partition coefficient data for heavy REE does not predict the behavior of $Y$. We speculate that mass fractionation effects play a role in mineral/melt lithophile trace element partitioning that is detectable among pairs of isovalent elements with near-identical radii, such as Y-Ho, $\mathrm{Zr}-\mathrm{Hf}$, and $\mathrm{Nb}-\mathrm{Ta}$.

\section{Introduction}

Clinopyroxene is one of the most abundant minerals in igneous rocks and plays a major role in the generation and subsequent differentiation of magma. Trace element partitioning between clinopyroxene and silicate liquid has therefore been the subject of intense study, especially since the successful application of lattice strain theory (Brice, 1975; Blundy and Wood, 1994) to crystal-melt element partitioning in igneous systems (Gaetani and Grove, 1995; Wood and Blundy, 1997, 2001, 2002; Blundy et al., 1998; Lundstrom et al., 1998; Hill et al., 2000; Pertermann and Hirschmann, 2002). Most of these studies focus on Mg-rich clinopyroxene and its role in influencing lithophile trace element abundances in basaltic magma. Consequently, the partitioning of rare earth elements into Mg-rich clinopyroxene is well characterized: light REE are incompatible, but compatibility increases with atomic number, typically flattening out between $\mathrm{Ho}$ and $\mathrm{Lu}$ (Fig. 1). In contrast, Fe-rich clinopyroxenes from many strongly differentiated systems show somewhat different behavior; the value of the partition coefficient $D$ [ $=($ concentration in solid phase $) /($ concentration in liquid $\left.), C_{\mathrm{s}} / C_{1}\right]$ rises with atomic number from the light to the middle REE, flattens out or declines slightly between Gd and Ho-Er, and distinctly rises to higher values at $\mathrm{Yb}$ and $\mathrm{Lu}$ (Fig. 1). Here, we describe enhanced heavy REE contents in natural Fe-rich clinopyroxene from phonolites and rhyolites. In Mg-rich clinopyroxene, REE are assumed to reside exclusively in 8-fold coordination on the M2 structural site. We show that the distinctive partitioning behavior of REE into Fe-rich pyroxenes is most simply explained by partial heavy REE occupancy of 6- 
fold coordinated sites with radii near those of $\mathrm{Fe}^{2+}$ and $\mathrm{Mn}^{2+}$; these may be located on either the M2 or M1 site (Cameron and Papike, 1980). We then describe a method for identifying equilibrium pyroxene-glass pairs on the basis of the complementary assumption that light and middle REE reside exclusively in 8-fold coordination. We also demonstrate significant $\mathrm{Y} / \mathrm{Ho}, \mathrm{Zr} / \mathrm{Hf}$ and $\mathrm{Nb} / \mathrm{Ta}$ fractionation between clinopyroxene and melt, and speculate that factors other than ionic radius and charge have a detectable effect on mineralmelt partitioning behavior of lithophile element cations.

\section{Samples}

Pyroxenes and glasses in this study come from three volcanic systems: Na-salites from the phonolitic Fasnia Member of the Diego Hernández Formation, Tenerife, Spain; ferrohedenbergites from the highsilica rhyolitic Bandelier Tuff, New Mexico, USA; and ferroaugites to ferrohedenbergites from the rhyolitic Rattlesnake Tuff, Oregon, USA.

Information about each system is summarized in Table 1 . The three magmas are all close to minimum melt compositions with $(\mathrm{Na}+\mathrm{K}) / \mathrm{Al} \approx 1$ and near-identical degrees of melt polymerization as indicated by the parameter $\mathrm{NBO} / \mathrm{T}$, but vary strongly in alkali content and silica saturation.

\section{Fasnia Member, Tenerife}

The $309 \pm 6$ ka Fasnia Member (FM) is one of the major units of the phonolitic, caldera-related Diego Hernández Formation of the Las Cañadas Upper Group on Tenerife (Martí et al., 1994; Edgar et al., 2007). Las Cañadas phonolites have whole-rock compositions that lie close to the 1 kbar water-saturated phonolitic minimum in the ne-ks-Q system (Hamilton \& MacKenzie, 1965), oxygen fugacities that lie close to the NNO buffer (Wolff \& Storey, 1983) and temperatures typically in the range $790-850^{\circ} \mathrm{C}$ (Wolff \& Storey, 1983; Bryan, 2006; Andújar et al., 2008). In addition to the phenocryst phases listed in Table 1, the FM contains trace amounts of apatite and pyrrhotite as inclusions in other minerals. The FM is the product the explosive eruption of $\sim 13 \mathrm{~km}^{3}$ of phonolite magma with a large range in trace element abundances (Edgar et al., 2007), due to mixing of at least two distinct end member phonolites and a small volume of mafic magma that resulted in a dominant volume of hybrid phonolite (Olin, 2007). Despite variable trace element contents (Table 2), fresh FM glasses considered here exhibit very little variation in major elements, with approximately $15 \mathrm{wt} . \%$ total alkalies and $(\mathrm{Na}+\mathrm{K}) / \mathrm{Al} \approx 1$.

Sodian salites analyzed in this study have near-constant major element compositions (Fig. 2) and trace element contents that are consistent with having crystallized from the hybrid FM magma (Olin, 2007). Individual pyroxene grains are euhedral and do not display detectable zoning in either major or trace elements.

\section{Bandelier Tuff}

The $\sim 450 \mathrm{~km}^{3}$ Otowi Member of the Bandelier Tuff (BT) erupted from the Valles caldera, New Mexico, at 1.61 Ma. The BT is a high-silica rhyolite with a composition that closely corresponds to the water-saturated granite minimum between 1 and 2 kbar (Tuttle \& Bowen, 1958). The phenocryst assemblage contains quartz, magnetite and fayalite and $\mathrm{O}_{2}$ is therefore presumed to lie close to the QMF buffer. Trace amounts of zircon and allanite occur in addition to the phenocrysts listed in Table 1, and chevkinite and britholite are present as inclusions in clinopyroxene, fayalite, and magnetite (Min et al., 2006). The tuff displays strong vertical zonation in incompatible trace elements (Spell et al., 1990; Wolff et al., 1999); euhedral ferrohedenbergites and glasses analyzed in this study come from the most differentiated, chemically homogeneous, first-erupted portion of the magma body.

\section{Rattlesnake Tuff}

The 7.05 Ma Rattlesnake Tuff (RT) represents the explosive eruption of $\sim 280 \mathrm{~km}^{3}$ of multi-component rhyolitic magma (Streck \& Grunder, 1997, 2007). The RT contains five distinct high silica rhyolite compositions, A, B, C, D, and E (Streck \& Grunder 1997), related primarily by fractional crystallization where type A rhyolite is the most differentiated and type $\mathrm{E}$ is the least differentiated. Glasses and 
pyroxenes from RT rhyolites type C, D, and E were analyzed in this study, and due to their similarities in trace element contents, respectively (Streck \& Grunder, 1997), are treated as one population. In addition to the phases listed in Table 1, trace amounts of biotite occur in rhyolite types C - E, plus the accessory minerals zircon, chevkinite, apatite and pyrrhotite. The RT pyroxenes span a major-element compositional range from $\mathrm{Mg} \#=9.6$ associated with type $\mathrm{E}$ rhyolite with $\sim 74 \mathrm{wt} \% \mathrm{SiO}_{2}$ to pyroxenes with values as high as $\mathrm{Mg} \#=31.7$ in type $\mathrm{C}$ rhyolite with $\sim 77 \mathrm{wt} \% \mathrm{SiO}_{2}$.

\section{Analytical Methods}

All data were generated in the Washington State University GeoAnalytical Laboratory using laser ablation and solution ICP-MS analysis of trace element concentrations and electron microprobe for major element analysis, except for BT hedenbergite major element microprobe data from Kuentz (1986). Trace element concentrations in FM, BT and RT pyroxenes and FM and BT glasses were measured by ablating shallow $(<5 \mu \mathrm{m}$ deep $)$ troughs with a New Wave $213 \mathrm{~nm}$ laser coupled to an Element2 high-resolution mass spectrometer. For pyroxenes, ablation troughs were 12 to $20 \mu \mathrm{m}$ wide by 0.5 to $1 \mathrm{~mm}$ long. Grains were analyzed in situ where encountered in polished sections (for FM and BT samples) or as mineral separates mounted in epoxy (for FM, BT and RT samples). Trace element concentrations in pumiceous glasses from the FM and BT were determined using LA-ICP-MS in situ on polished sections. Laser tracks were positioned to follow along bubble walls in pumice resulting in 5 to $8 \mu \mathrm{m}$-wide troughs with irregular geometries and lengths of $200-500 \mu \mathrm{m}$. For both pyroxenes and glasses, acquired counts per second data were reduced offline and internally normalized to the electron microprobe determined $\mathrm{SiO}_{2}$ contents and laser determined ${ }^{29} \mathrm{Si}$ counts per second. Two-point calibrations were constructed using BCR-2g and either NIST 610 or NIST 612 as standards.

Glass shard separates from the RT were too small for mounting and polishing and their trace element contents were therefore determined using a small-scale dissolution technique on small aliquots (3 to $11 \mathrm{mg}$ ) repeated three times for each sample and averaged. Glass separates were dissolved in a two-step digestion

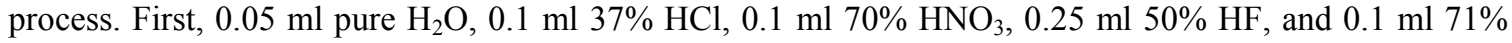
$\mathrm{HClO}_{4}$ were added to each sample vial. Vials were capped overnight and held on a hotplate at $130^{\circ} \mathrm{C}$, then uncapped and allowed to evaporate to dryness. Next, $0.05 \mathrm{ml}$ pure $\mathrm{H}_{2} \mathrm{O}$ and $0.1 \mathrm{ml} 70 \% \mathrm{HClO}_{4}$ were added, and evaporated to dryness again. The final solutions were gravimetrically diluted to $30 \mathrm{mg}$ in $2 \% \mathrm{HNO}_{3}$ with 4 drops $30 \% \mathrm{H}_{2} \mathrm{O}_{2}$ and 1 drop $50 \%$ HF. Solutions were analyzed on an Element 2 mass spectrometer coupled to a Cetac Aridus desolvating nebulizer to increase sensitivity and to reduce oxides. International standards BCR-2, BHVO-1, and in-house standard GMP were used for calibration. A comparison of BCR$2 \mathrm{~g}$ and an in-house pyroxene standard (TFPX4) analyzed by both laser ablation and solution methods is shown in Fig. 3; there is no significant difference in REE contents analyzed by the two methods.

Gadolinium is not used in this study; there are unresolved issues with the ${ }^{157} \mathrm{Gd}$ isotope in many of the laser ablation analyses of both pyroxenes and glasses. Scandium contents in BT glasses are below the detection limits of the laser ablation procedure, while doubly charged zirconium $\left({ }^{90} \mathrm{Zr}^{2+}\right)$ in the very $\mathrm{Zr}$-rich FM phonolite glasses interferes with ${ }^{45} \mathrm{Sc}$; consequently, $D_{\mathrm{Sc}}$ is only reported for the RT system.

Major elements in FM and RT pyroxenes were measured using a Cameca electron microprobe in the Washington State University GeoAnalytical Laboratory. The instrument was operated at $15 \mathrm{kv}$, using a spot diameter of $\sim 4$ microns and a beam current of $12 \mathrm{nA}$.

\section{Pyroxene chemistry}

The Fasnia pyroxenes are sodic salites $\left(\mathrm{Wo}_{49} \mathrm{En}_{31} \mathrm{Fs}_{20}\right.$ to $\left.\mathrm{Wo}_{45} \mathrm{En}_{28} \mathrm{Fs}_{27}\right)$, the $\mathrm{BT}$ pyroxenes are ferrohedenbergites to ferroaugites $\left(\mathrm{Wo}_{44} \mathrm{En}_{10} \mathrm{Fs}_{46}\right.$ to $\left.\mathrm{Wo}_{40} \mathrm{En}_{10} \mathrm{Fs}_{50}\right)$, and RT pyroxenes are ferroaugites to ferrohedenbergites $\left(\mathrm{Wo}_{43} \mathrm{En}_{20} \mathrm{Fs}_{37}\right.$ to $\left.\mathrm{Wo}_{41} \mathrm{En}_{6} \mathrm{Fs}_{53}\right)$ in the pyroxene quadrilateral of Poldervaart and Hess (1951); see Fig. 2. The RT and BT pyroxenes have similar major and trace element contents, but are significantly different from the Na-salites (Table 2 and Figs. 4), which have higher $\mathrm{Na}, \mathrm{Mg}, \mathrm{Al}$, and $\mathrm{Ti}$ contents, and lower $\mathrm{Fe}, \mathrm{Mn}$ and $\mathrm{Si}$ contents. 
Compositional differences between hedenbergites and salites result in contrasting major element cation site assignments. Silicon occupies the $\mathrm{T}$-site and $\mathrm{Al}$ makes up any $\mathrm{Si}$ shortfall in tetrahedral coordination. $\mathrm{Si}+\mathrm{Al}$ is approximately equal to 2 pfu for all pyroxenes. M1 hosts all $\mathrm{Ti}^{4+}$ and also hosts $\mathrm{Fe}, \mathrm{Mn}$, and $\mathrm{Mg}$, but significant $\mathrm{Ca}+\mathrm{Na}$ shortfalls $(<1 \mathrm{pfu})$ in the hedenbergites require that at least some $\mathrm{Fe}$ and $\mathrm{Mn}$, and probably Mg, occupy M2. In the Na-salites this substitution is minor.

For the sake of simplicity and consistency, we calculate $\mathrm{Fe}^{3+}$ contents for all the pyroxenes using the stoichiometric assumption of Droop (1987). Approximately 50\% of total Fe in the FM pyroxenes, $10 \%$ of total $\mathrm{Fe}$ in the RT pyroxenes, and $<10 \%$ of total $\mathrm{Fe}$ in the $\mathrm{BT}$ pyroxenes is found to be $\mathrm{Fe}^{3+}$. We assume no preferential ordering of $\mathrm{Mn}, \mathrm{Fe}$, and $\mathrm{Mg}$ into $\mathrm{M} 2$ and $\mathrm{M} 1$ structural sites in the pyroxenes, rather we calculate sizes for the 6-fold coordinated site from the weighted average of $\mathrm{Mn}, \mathrm{Fe}^{2+}, \mathrm{Fe}^{3+}$, and $\mathrm{Mg}$ contents. All $\mathrm{Fe}^{3+}$ is considered to be in 6-fold coordination.

\section{Trace element partitioning between pyroxenes and glasses}

\section{Mineral chemistry effects}

The lattice structure of clinopyroxene changes in response to changing $\mathrm{Fe} / \mathrm{Mg}$ and $\mathrm{Na} / \mathrm{Ca}$ due to the size differences between $\mathrm{Na}$ and $\mathrm{Ca}$, and $\mathrm{Fe}$ and $\mathrm{Mg}$ (Cameron and Papike, 1980). Since $\mathrm{Mn}$ is slightly larger than $\mathrm{Fe}^{2+}$ (Shannon, 1976), incorporation of Mn must also result in structural changes. These structural changes should have consequences for trace element partitioning behavior, which should therefore differ between $\mathrm{Fe}$-rich and the more common $\mathrm{Mg}$-rich pyroxenes.

Pyroxene has the general formula $[\mathrm{M} 2][\mathrm{M} 1]\left[\mathrm{T}_{2} \mathrm{O}_{6}\right]$. The tetrahedral site (T) is filled with $\mathrm{Si}$ and lesser amounts of ${ }^{\mathrm{IV}} \mathrm{Al}$. The M2 polyhedron is larger and always more distorted than M1 (Cameron and Papike, 1980) and will accommodate VI-, VII- and VIII-coordinated univalent, divalent and trivalent cations with ionic radii from $\sim 0.72 \AA\left({ }^{\mathrm{VI}} \mathrm{Mg}\right)$ to $\sim 1.16 \AA$ ( $\left.{ }^{\mathrm{VIII}} \mathrm{Na}\right)$. Sevenfold coordination has only been described for some pigeonites (Cameron and Papike, 1980) and is not considered further here. A preference for either M1 or M2 is influenced by anion configuration around each site, and by the ionic radius and electronegativity of the cations (Cameron and Papike, 1980). M1 is the smaller of the two cation sites and accommodates divalent, trivalent, tetravalent, and pentavalent cations in 6-fold coordination, with ionic radii between $\sim 0.53 \AA\left({ }^{\mathrm{VI}} \mathrm{Al}^{3+}\right)$ and $\sim 0.83 \AA\left({ }^{\mathrm{VI}} \mathrm{Mn}^{2+}\right)$. Larger cations such as ${ }^{\mathrm{VIII}} \mathrm{Na}(1.18 \AA)$ and ${ }^{\mathrm{VIII}} \mathrm{Ca}(1.12 \AA)$ will prefer M2 to M1 (Robinson, 1980).

\section{REE partitioning model}

In the lattice strain model (LSM) of Brice (1975) and Blundy and Wood (1994), the partition coefficient $D_{\mathrm{i}}$ at equilibrium of a cation with radius $r_{\mathrm{i}}$ entering a particular crystal lattice site $\mathrm{M}$ is given by

$$
D_{\mathrm{i}}=D_{0} * \exp \left\{-4 \pi E_{\mathrm{M}} N_{\mathrm{A}}\left[r_{0}\left(r_{\mathrm{i}}-r_{0}\right)^{2} / 2+\left(r_{\mathrm{i}}-r_{0}\right)^{3} / 3\right] / R T\right\}
$$

where $D_{0}$ is the partition coefficient of an isovalent ion of radius $r_{0}$ which enters the site without strain, $E_{\mathrm{M}}$ is the Young's modulus of site $\mathrm{M}, \mathrm{N}_{\mathrm{A}}$ is Avogadro's Number, $R$ is the universal gas constant, and $T$ is temperature in Kelvin. The relationship is most often plotted on an Onuma diagram as the logarithm of the partition coefficient versus ionic radius, producing a parabolic distribution (Fig. 5a). The partition coefficient $D_{0}$ for a cation with optimal radius $r_{0}$ fixes the apex of the parabola, and its curvature is controlled by the Young's modulus $\left(E_{\mathrm{M}}\right)$ for the site. Larger $E_{\mathrm{M}}$ values 'tighten' the parabola, reflecting greater stiffness of the site and therefore a relatively narrower range of radii for cations that significantly substitute into the site. For the application of the model below, it is not necessary to know $r_{0}$ and $D_{0} a$ priori as long as there are enough elements to plot to define the shape of the parabola.

Numerous studies have successfully applied the LSM to mineral-melt partitioning, especially for Ca-Mg pyroxenes (Wood and Blundy, 1997; Vannucci et al., 1998; Hill et al., 2000; Wood and Trigila, 2001; Tiepolo et al., 2002). These studies report smooth parabolic distributions of $\log D_{\mathrm{i}}$ vs. $r_{\mathrm{i}}$ for REE in pyroxenes that can be modeled by assuming that all $\mathrm{REE}^{3+}$ are substituting for eight-fold coordinated $\mathrm{Ca}^{2+}$. However, iron rich pyroxenes found in evolved felsic liquids (e.g. Larsen, 1979; Wörner et al., 1983; 
Mahood and Stimac, 1990; Fedele et al., 2009) show REE patterns with elevated partition coefficients from Er to Lu, rather than a simple parabolic form (Figs. 1, 6). Because heavy REE have ionic radii more similar to $\mathrm{Fe}$ and $\mathrm{Mn}$ in 6-fold coordination than $\mathrm{Ca}$ in eight-fold coordination (Table 3), we propose that elevated $D_{\text {HREE }}$ in Fe-rich pyroxenes reflects enhanced compatibility relative to lighter REE caused by heavy REE occurring in both eight-fold coordination (substituting for $\mathrm{Na}$ or $\mathrm{Ca}$ in $\mathrm{M} 2$ ) and 6-fold coordination (substituting for $\mathrm{Fe}$ and $\mathrm{Mn}$ in $\mathrm{M} 1$ or M2). If this is the case, then each coordination state $\left({ }^{\mathrm{VI}} \mathrm{REE}^{3+}\right.$ and $\left.{ }^{\mathrm{VIII}} \mathrm{REE}^{3+}\right)$ is governed by its own LSM equation, and mineral/melt $D$ values are the sum of the two parabolic functions (Figs. $5 \& 7$ ).

\section{Identification of pyroxene-glass pairs}

Before these relationships can be explored, it is necessary to establish that the pyroxene grains and glasses used to obtain $D$ values represent equilibrium pairs. One possible problem is late crystallization of accessory phases that concentrate REE and would therefore deplete the melt in REE after pyroxene growth. While we cannot completely rule out this effect, we note that it would tend to deplete middle REE in FM glasses and light REE in the rhyolitic glasses, thus enhancing the apparent $D$ values for these elements with respect to heavy REE, the opposite of what we in fact observe. In fact, the FM pyroxenes have a deeper middle REE trough than do the glasses (Fig. 3).

In all three examples, pyroxene grains are euhedral and appear to be in textural equilibrium with the enclosing glass. However, in the case of the compositionally variable Fasnia phonolite, magmatic processes have scrambled crystals and glasses (Olin, 2007), precluding confident identification of mineralglass pairs based on physical proximity or grain shape. The method outlined below is independent of major element mineral compositions, assumes that the LSM is a good first-order predictor of trace element partition coefficients, and does not rely on textural relationships. A crucial assumption is that the light and middle REE (La - Dy) are not partitioned between 6-fold and 8-fold sites, but reside exclusively on the 8fold site. We emphasize that, qualitatively, our finding of elevated pyroxene/melt partition coefficients for heavy REE remains robust even if mineral-melt pairs are randomly assigned within each of the three systems. We make the effort to identify equilibrium pairs in order to isolate and quantify the heavy REE enrichment in the pyroxenes to the maximum extent allowed by the data.

For $25 \mathrm{FM} \mathrm{Na-salite} \mathrm{and} 44 \mathrm{BT}$ hedenbergite grains, apparent $D_{\mathrm{REE}}$ values were calculated using LA-ICPMS-determined concentrations of $\mathrm{La}, \mathrm{Ce}, \mathrm{Pr}, \mathrm{Nd}, \mathrm{Sm}, \mathrm{Tb}$ and Dy (approximately 500 phonolite glasses in the case of the Fasnia and approximately 100 high-silica rhyolite glasses from the BT). Eu is omitted due its unconstrained oxidation state, and heavy REE $(\mathrm{Ho}-\mathrm{Lu}$ ) for the reasons outlined above. Equilibrium between the pyroxenes and the different glasses is evaluated by assuming that isovalent cations entering a single lattice site will always follow a parabolic distribution in $\log D_{\mathrm{i}} \mathrm{vs} . r_{\mathrm{i}}$, using equation (1) rewritten as:

$$
\left[R T /\left(-4 \pi N_{\mathrm{A}}\right)\right] *\left[\ln \left(D_{\mathrm{i}} / D_{0}\right)\right]=E_{\mathrm{M}}\left[r_{0} / 2 *\left(r_{\mathrm{i}}-r_{0}\right)^{2}+1 / 3 *\left(r_{\mathrm{i}}-r_{0}\right)^{3}\right]
$$

If the data follow the parabolic function exactly, the result is a straight line with slope $E_{\mathrm{M}}$ (Fig. 5c). Using equation (2) with the selected $\mathrm{REE}^{3+} \mathrm{La}$ to $\mathrm{Dy}$, the pyroxene-glass pair with the best $R^{2}$ correlation coefficient for the linear regression represents the closest approach to equilibrium and yields pyroxene-melt partition coefficients. We applied a filter of $R^{2}>0.95$ to 12,500 possible pyroxene-glass pairings from the FM and 6,400 pairs from the BT, yielding 300 and 220 near-equilibrium pairs respectively. This approach is more rigorous than simply using predicted absolute $D$ values because the fit does not depend on knowing $D_{0}$ or $r_{0}$, and relies on multiple elements. For the $40 \mathrm{RT}$ pyroxenes, partition coefficients were calculated using pyroxenes paired with equilibrium glasses identified by Streck and Grunder (1997) and re-analyzed for this study.

From equation (2), the resultant calculated ${ }^{\mathrm{VIII}} E^{3+}{ }_{\mathrm{M} 2}$ values for the Na-salites are $113-240 \mathrm{GPa}$ (ave. 177 $\mathrm{GPa}$ ), for BT hedenbergites $306-387 \mathrm{GPa}$ (ave. $339 \mathrm{GPa}$ ) and for the RT ferroaugites 249 to $358 \mathrm{GPa}$ (ave. $296 \mathrm{GPa}$ ). Our estimates of ${ }^{\mathrm{VIII}} E^{3+}{ }_{\mathrm{M} 2}$ for the BT and RT pyroxenes compare well with published values of 256 to $387 \mathrm{GPa}$ (Hill et al., 2000; Lundstrom et al., 1998). Those for the FM Na-salites are lower due to the influence of $\mathrm{Na}$, a result also found experimentally by Bennett et al. (2004). 
Model curves fitted to the average pyroxene-glass partition coefficients for each of the three populations are plotted on Figure 7. Parameters for each model curve are given in Table 4. Temperatures are from the literature for each system: Fasnia, assumed similar to other Tenerife phonolites, $825^{\circ} \mathrm{C}$ (Andujar et al., 2008); RT, $800^{\circ} \mathrm{C}$ (Streck and Grunder, 1997); and BT at $700^{\circ} \mathrm{C}$ (Warshaw and Smith, 1988). Values for the other parameters used in the model curves are determined in a two-step approach. First, values for the eight-fold coordination LSM equation come from equilibrium pyroxene-glass pairs identified using LREE and MREE in equation (2). This results in eight-fold coordination model values of: ${ }^{\mathrm{VIII}} r_{0}=1.06 \AA$, ${ }^{\mathrm{VIII}} D_{0}=$ 1.6 , and ${ }^{\mathrm{VIII}} E^{3+}{ }_{\mathrm{M} 2}=177 \mathrm{GPa}$ for Na-salite; ${ }^{\mathrm{VIII}} r_{0}=1.055 \AA$, ${ }^{\mathrm{VIII}} D_{0}=5.2$, and ${ }^{\mathrm{VIII}} E^{3+}{ }_{\mathrm{M} 2}=296 \mathrm{GPa}$ for RT hedenbergites; and ${ }^{\mathrm{VIII}} r_{0}=1.055 \AA$, ${ }^{\mathrm{VIII}} D_{0}=9$, and ${ }^{\mathrm{VIII}} E^{3+}{ }_{\mathrm{M} 2}=339 \mathrm{GPa}$ for BT hedenbergites. Then, plausible values are chosen for the six-fold coordination LSM equation to fit the cumulative (VIII-fold + VI-fold) curves through the data, i.e., the heavy REE. The value of ${ }^{\mathrm{VI}} r_{0}=0.724 \AA, 0.758 \AA$ and $0.772 \AA$ for FM, RT and BT pyroxenes, respectively, is derived from the combined effective ionic radius, or weighted average, of the $\mathrm{Fe}^{2+}, \mathrm{Fe}^{3+}, \mathrm{Mn}$, and $\mathrm{Mg}$ contents, and allows the model to be reasonably fitted through the $D_{\text {HREE }}$ and the notably high $D_{\mathrm{Sc}}$ values for RT hedenbergites. For FM Na-salites ${ }^{\mathrm{VI}} D_{0}=500$ and ${ }^{\mathrm{VI}} E^{3+}{ }_{\mathrm{M}}=$ $775 \mathrm{GPa}$, for RT hedenbergites ${ }^{\mathrm{VI}} D_{0}=150$ and ${ }^{\mathrm{VI}} E^{3+}{ }_{\mathrm{M}}=1000 \mathrm{GPa}$, and for BT hedenbergites ${ }^{\mathrm{VI}} D_{0}=200$ and ${ }^{\mathrm{VI}} E^{3+}{ }_{\mathrm{M}}=1100 \mathrm{GPa}$. The ${ }^{\mathrm{VI}} E^{3+}{ }_{\mathrm{M}}$ values found here are comparable to values determined for diopside by Hill et al. (2000), Lundstrom et al. (1998) and Hazen \& Finger (1979). It should be noted that ${ }^{\mathrm{VI}} D_{0}$ values are quite sensitive to small changes in ${ }^{\mathrm{VI}} r_{0}$ in the sixfold model equation. This is a function of the higher ${ }^{\mathrm{VI}} E_{\mathrm{M}}$ values for this coordination state (Hill et al., 2000).

Immediately apparent from this exercise is that the negative $\mathrm{D}_{\mathrm{Y}}$ anomaly seen in $\mathrm{FM}, \mathrm{RT}, \mathrm{BT}$, and other iron-rich pyroxenes (Figs. 1,7) is not explained by the LSM, which predicts a smooth pattern across Dy, Y and Ho. This feature is discussed below.

\section{Trace element partition coefficients}

Each of the three Fe-rich clinopyroxene populations studied here exhibits a significant range in $\mathrm{D}_{\mathrm{REE}}$, (Figs. 6 - 9; Table 5). Na-salites have the following ranges in D-values for selected REE and Y (YREE): $\mathrm{D}_{\mathrm{La}} 0.4$ to 1.1 (aver. 0.6), $\mathrm{D}_{\mathrm{Sm}} 1.0$ to 2.4 (aver. 1.5), $\mathrm{D}_{\mathrm{Lu}} 3.5$ to 5.9 (aver. 4.5 ), and $\mathrm{D}_{\mathrm{Y}} 0.9$ to 1.8 (aver. 1.3). RT hedenbergites have $\mathrm{D}_{\mathrm{La}} 0.7$ to 1.2 (aver. 1.0), $\mathrm{D}_{\mathrm{Sm}} 2.9$ to 6.6 (aver. 5.0), $\mathrm{D}_{\mathrm{Lu}} 4.0$ to 7.9 (aver. 6.0), and $\mathrm{D}_{\mathrm{Y}} 2.1$ to 4.8 (aver. 3.7). BT hedenbergites have $\mathrm{D}_{\mathrm{La}} 0.9$ to 2.3 (aver. 1.2), $\mathrm{D}_{\mathrm{Sm}} 6.3$ to 15 (aver. 8.0), $\mathrm{D}_{\mathrm{Lu}} 7.1$ to 14 (aver. 10), and $\mathrm{D}_{\mathrm{Y}} 3.8$ to 7.2 (aver. 4.8). $\mathrm{D}_{\mathrm{REE}}$ are positively correlated with each other as indicated by the uniform increase of D-values in Figure 5. In general, and especially in ferrohedenbergites from the BT, $\mathrm{Y}$ is less compatible into pyroxene than heavy REE of similar radius (Figs. 7, 8); this behavior is discussed below. Calculated D values for LREE and MREE are generally comparable to published values from a range of magma compositions (e.g., Sisson, 1991; Hart and Dunn, 1993; Schosnig and Hoffer, 1998; Hill et al., 2000; Bennett et al., 2004; Huang et al., 2006; Lofgren et al., 2006), but values for heavy REE are significantly higher relative to middle REE. Comparison of FM and RT pyroxenes shows that $\mathrm{D}_{\mathrm{Lu}}$ increases with increasing $\mathrm{Fe}^{2+}$ and $\mathrm{Mn}$ contents. Among the RT hedenbergites, $\mathrm{D}_{\mathrm{Lu}}$ is however negatively correlated with Fe contents, but positively correlated with Mn contents (Fig. 9).

Partition coefficients for HFSE are shown in Figure 8 and Table 5. Na-salites have the following selected $\mathrm{D}_{\mathrm{HFSE}}$ : $\mathrm{D}_{\mathrm{Ti}} 0.8$ to 1.9 (aver. 1.3 ), $\mathrm{D}_{\mathrm{Zr}} 0.7$ to 1.7 (aver. 1.2), and $\mathrm{D}_{\mathrm{Hf}} 1.0$ to 2.8 (aver. 1.8). RT hedenbergites have $\mathrm{D}_{\mathrm{Ti}} 1.2$ to 2.0 (aver. 1.5 ), $\mathrm{D}_{\mathrm{Zr}} 0.16$ to 0.26 (aver. 0.21 ), and $\mathrm{D}_{\mathrm{Hf}} 0.22$ to 0.37 (aver. 0.28). $\mathrm{BT}$ hedenbergites have $\mathrm{D}_{\mathrm{Ti}} 1.3$ to 2.0 (aver. 1.6), $\mathrm{D}_{\mathrm{Zr}} 0.17$ to 0.40 (aver. 0.26 ), and $\mathrm{D}_{\mathrm{Hf}} 0.27$ to 0.98 (aver. 0.44). In all pyroxenes studied $\mathrm{D}_{\mathrm{Hf}}>\mathrm{D}_{\mathrm{Zr}}$ and $\mathrm{D}_{\mathrm{Ho}}>\mathrm{D}_{\mathrm{Y}}$, and in the Na-salites $\mathrm{D}_{\mathrm{Ta}}>\mathrm{D}_{\mathrm{Nb}}$ (Ta contents in $\mathrm{BT}$ and RT pyroxenes were below detection limits). Calculated HFSE partition coefficients are generally comparable to other published values (e.g., Sisson, 1991; Hart and Dunn, 1993; Schosnig and Hoffer, 1998; Hill et al., 2000; Bennett et al., 2004; Marks et al., 2004; Huang et al., 2006; Lofgren et al., 2006). 


\section{Discussion}

\section{Factors controlling HREE enrichment in pyroxene}

The primary factors controlling the style of trace element partitioning between clinopyroxene and silicate melt are mineral composition and the ionic radius of the substituting cation. The generally lower ${ }^{V I I I} E^{3+}$ values for $\mathrm{Na}$-salites relative to the ferrohedenbergites and ferroaugites is attributed to their higher $\mathrm{Na}$ contents ; Na cations have the effect of opening the calcic pyroxene structure and lowering ${ }^{\text {VIII }} E^{3+}$ (Bennett et al., 2004).

We have shown that the HREE enrichment of these pyroxenes is plausibly explained by their high Fe contents (i.e., $\mathrm{Fe}^{2+}$ ) that are common to all three groups studied here, but variations in $D_{\text {HREE }}$ within the FM and RT pyroxene populations are not apparently controlled by Fe contents alone (Fig. 9); considering the RT pyroxenes in isolation, $D_{\mathrm{Lu}}$ is strongly positively correlated with $\mathrm{Mn}$ contents, but negatively correlated with Fe contents. This suggests that $\mathrm{Mn}$, in fact, has a more powerful effect than $\mathrm{Fe}^{2+}$ in creating the space for 6-fold coordinated heavy REE to substitute into the pyroxene structure. This is consistent with Mn having the larger ionic radius.

\section{Fractionation of $\mathrm{Y} / \mathrm{Ho}, \mathrm{Zr} / \mathrm{H} f$, and $\mathrm{Nb} / \mathrm{Ta}$}

The elements in each of these pairs have closely similar radii and have been viewed in the past as chemically identical at magmatic temperatures. Thus, Y was commonly used as a proxy for the HREE between $\mathrm{Tb}$ and $\mathrm{Yb}$ prior to the routine availability of high-quality ICPMS data for all 14 REE (for example, Thompson et al., 1984). Significant fractionation in these pairs of elements is observed at submagmatic temperatures (Bau, 1996, 1999; Bau and Dulski, 1999) and, in plutonic rocks, has been ascribed to the action of aqueous fluids during the final stages of crystallization (Irber, 1999). Carbonatite liquids have also been implicated in $\mathrm{Zr} / \mathrm{Hf}$ and $\mathrm{Nb} / \mathrm{Ta}$ fractionation (Rudnik et al., 1993). Nonetheless, it is now well established that these element pairs are fractionated during common crystallization-differentiation processes. Magmatic fractionation of $\mathrm{Nb}$ from Ta was first demonstrated by Wolff (1984) in Tenerife phonolites and shown to be due to titanite crystallization; Ti-rich phases in general have high $D$ values for HFSE and are effective in separating these two elements (Green and Pearson, 1986). The restricted $P-T-X$ conditions under which phases such as titanite and rutile are stable has lead to considerable attention being paid to variations in $\mathrm{Nb} / \mathrm{Ta}$, in particular, among different terrestrial reservoirs (Rudnik et al., 1993; Collerson et al., 2007; Horng and Hess, 2000; Wade and Wood, 2001; Foley et al., 2002). With the advent of high-quality mineral-melt partitioning data, it has become clear that common phases such as clinopyroxene and amphibole also fractionate $\mathrm{Y}$ from $\mathrm{Ho}, \mathrm{Zr}$ from $\mathrm{Hf}$, and $\mathrm{Nb}$ from $\mathrm{Ta}$ (Lundstrom et al., 1998; Tiepolo et al., 2002).

The ability of the LSM to predict these fractionations depends on accurate ionic radius data. $\mathrm{Nb}^{5+}$ and $\mathrm{Ta}^{5+}$ are conventionally viewed as having identical radii, $\mathrm{Zr}^{4+}$ and $\mathrm{Hf}^{4+}$ are slightly different, while the radius of $\mathrm{Y}^{3+}$ lies between those of $\mathrm{Dy}^{3+}$ and $\mathrm{Ho}^{3+}$ in eight-fold coordination, but is nearly identical to $\mathrm{Ho}^{3+}$ in 6 -fold coordination (Shannon 1976; relevant values are reproduced in Table 3. Note that in the older compilation of Whittaker \& Muntus, 1970, the ionic radii of $\mathrm{Y}^{3+}$ and $\mathrm{Ho}^{3+}$ are equal in both 6-fold and 8-fold coordination). Accuracy of the LSM is difficult to assess for $\mathrm{Nb}-\mathrm{Ta}$ and $\mathrm{Zr}-\mathrm{Hf}$, because the very high $E$ values associated with high valencies and the small M1 site in clinopyroxene imply easily detectable changes in $D$ at variations in $r \leq 0.01 \AA$, beyond the resolution of the Shannon (1976) ionic radius data. Blundy and Wood (2003) in fact propose that the ionic radius of $\mathrm{Ta}^{5+}$ is $0.01-0.02 \AA$ smaller that that of $\mathrm{Nb}^{5+}$, based on $D_{\mathrm{Nb}} / D_{\mathrm{Ta}}$ variations in Ti-pargasite and kaersutite documented by Tiepolo et al. (2002). However, inspection of Figure 7 shows that $\mathrm{Y}^{3+} \mathrm{cpx} / \mathrm{melt}$ partitioning deviates from that of the HREE to an extent that the LSM cannot explain unless the Shannon (1976) value of the ionic radius for $\mathrm{Y}^{3+}$ is grossly in error, and really lies within the range of ionic radii of the light REE! Titanite displays similar behavior to a greater degree (Olin, 2007). This result is not entirely unexpected; there can be little doubt that ionic radius and charge are more important than other factors in predicting D values, and so the effects of deviations from the LSM should be most apparent among isovalent cations of similar radii. Although small differences in ionic radius may indeed cause fractionation of $\mathrm{Nb}$ from $\mathrm{Ta}$ and $\mathrm{Zr}$ from $\mathrm{Hf}$, this cannot explain the fractionation of $\mathrm{Y}$ from the heavy REE. The pairs $\mathrm{Y}-\mathrm{Ho}, \mathrm{Zr}-\mathrm{Hf}$ and Nb-Ta share a common 
feature, which is that the lighter cation has the outer electronic configuration [Kr], and the heavier cation has buried $4 f$ electrons and the outer electronic configuration [Xe]. Contrasts in behavior between the members of each pair may therefore be due to electronic effects, such as the related properties of electronegativity and ionic polarizability, and/or mass effects.

\section{Sources of deviation from the LSM}

The LSM assumes that cations behave as 'billiard balls' with evenly distributed surface charge. Deviations are expected where outer electronic structure cannot be so modeled, for example crystal field effects resulting from the involvement of $d$ orbitals in bonding, or the presence of a lone pair of electrons (Blundy and Wood, 1994). The ions $\mathrm{Y}^{3+}, \mathrm{Ho}^{3+}, \mathrm{Zr}^{4+}, \mathrm{Hf}^{4+}, \mathrm{Nb}^{5+}$ and $\mathrm{Ta}^{5+}$ all have inert gas outer electronic configurations and therefore approximate to charged billiard balls, but exhibit variation in electronegativity and ionic polarizability (Table 6), i.e. the tendency to develop uneven charge distribution.

Horng and Hess (2002) invoked the polarizability difference of $\mathrm{Nb}_{2} \mathrm{O}_{5}$ and $\mathrm{Ta}_{2} \mathrm{O}_{5}$ (as a proxy for $\mathrm{NbO}_{6}$ and $\mathrm{TaO}_{6}$ octahedra in minerals and melts), calculated from specific refractivity values tabulated by Jaffe (1988), to explain experimentally-determined fractionation of $\mathrm{Nb} / \mathrm{Ta}$ between rutile and haplogranite melt. Using the same tabulation (Table 6), polarization effects are predicted to operate in one sense for Y-HREE and $\mathrm{Zr}-\mathrm{Hf}$, and in the opposite sense for $\mathrm{Nb}$-Ta. Using the more recent compilation of ionic polarizabilities of Shannon and Fischer (2006), dipole effects for Y-HREE should act in the opposite sense to Zr-Hf and $\mathrm{Nb}-\mathrm{Ta}$ (Table 6). The differences in electronegativity and polarizability between Y and HREE are also small. Although not consistent in the prediction of $\mathrm{Zr}-\mathrm{Hf}$ behavior, both approaches predict opposite senses of Y-Ho and $\mathrm{Nb}$-Ta partitioning. This contrasts with our data, which shows that the heavy element in each pair is always the more compatible. With the understanding that as yet undetected differences in ionic radius may trump secondary effects, we briefly speculate on the possible role of mass effects.

\section{Mass fractionation effects?}

By analogy with the theoretical treatment of stable isotope fractionation (Chacko et al., 2001), mass fractionation between two otherwise identical ions may be crudely approximated by treating the metaloxide bond as a diatomic molecule that behaves as a simple harmonic oscillator (spring) connecting two masses $m_{\mathrm{M}}$ and $m_{\mathrm{O}}$, where $\mathrm{M}$ and $\mathrm{O}$ denote the metal and oxygen respectively. The vibrational frequency, $v$, of the oscillator is given by

$$
v=(k / \mu)^{0.5} / 2 \pi
$$

$\square \square \square \square \square \mathrm{k}$ s the force constant of the spring (a property related to the elastic modulus), and $\mu$ is the reduced mass, given by $\mu=m_{\mathrm{M}} m_{\mathrm{O}} /\left(m_{\mathrm{M}}+m_{\mathrm{O}}\right)$. In this model, a strong chemical bond can be thought of as a spring with a high force constant, resulting in a higher vibrational frequency. From equation (3), changing the mass of the metal ion gives

$$
v^{*} / v=\left(\mu / \mu^{*}\right)^{0.5}
$$

where the asterisk denotes substitution of the heavier atom. Due to the inverse relation between frequency and mass, the heavy molecule has a lower vibrational frequency than the lighter molecule and hence is more energetically stable. Partitioning between two phases then depends on their competition for the heavy atom. Equation (4) can be rearranged to yield

$$
v-v^{*}=v\left[1-\left(\mu / \mu^{*}\right)^{0.5}\right]
$$

from which it can be seen that the heavy atom favors the phase with stronger M-O bonds (higher $v$ ).

Because we have no information on the strengths of trace metal - oxygen bonds in silicate liquids, we cannot make quantitative estimates of pyroxene-melt mass fractionation effects for trace elements. Nonetheless, some qualitative predictions are possible based on equations (3) - (5). First, the sign of 
heavy/light partitioning should always be the same for any given phase/melt pair, i.e., either the heavy or the light element should prefer the solid phase for each of the pairs $\mathrm{Y}-\mathrm{Ho}, \mathrm{Zr}-\mathrm{Hf}$, and $\mathrm{Nb}-\mathrm{Ta}$. Second, we expect that the mineral phase will in most cases favor the heavy element in each pair. This is because M-O bonds in silicate liquids are assumed to be considerably weaker than the same bonds in solid phases; the very success of the LSM, which ignores melt structural effects, in predicting first-order partitioning behavior supports this assumption. Our data, plus a review of the literature for pyroxene-melt, amphibolemelt, titanite-melt, rutile-melt, magnetite-melt, and ilmenite-melt partitioning of $\mathrm{Y} / \mathrm{Ho}, \mathrm{Zr} / \mathrm{Hf}$ and $\mathrm{Nb} / \mathrm{Ta}$ reveals that in each case the partition coefficients are higher for the heavier elements (e.g., Stimac and Hickmott, 1994; Bottazzi et al., 1999; Oberti et al., 2000; Horng and Hess, 2000; Nielsen and Beard, 2000; Tiepolo et al., 2002; Prowatke and Klemme, 2005). This would be a remarkable coincidence if small differences in radii were solely responsible, given the variety of phases and lattice sites represented. Third, the discrepancy between partitioning behavior of the heavy and light element in each pair should increase with ionic charge. This is because $\left(n-n^{*}\right) / n$ values (eqn. 5) are approximately constant $(0.0365 \pm 0.007)$ for each of the three element pairs, but M-O bond strength is expected to increase with increasing charge on $\mathrm{M}$, all else equal, and so the mass fractionation effect should be enhanced. This effect is seen in our data (Fig. 8). Finally, mass fractionation effects are expected to be inversely correlated with temperature. This effect is also seen in our data (Figure 8), for which $T_{\text {Fasnia }}>T_{\mathrm{RT}}>T_{\mathrm{BT}}$.

Niu \& Hékinian (1997) and Niu (2004) also appealed to mass-dependent fractionation as a possible explanation for large variations in $\mathrm{Zr} / \mathrm{Hf}$ and $\mathrm{Nb} / \mathrm{Ta}$ among abyssal peridotites, and noted that kinetic effects enhance mass fractionation because diffusion coefficients are themselves mass dependent. It is possible that, at the relatively low magmatic temperatures of the systems investigated here, chemical kinetics could play a detectable role in cation partitioning between pyroxene and melt, and may be more marked than equilibrium mass fractionation effects. Variable $\mathrm{Y} / \mathrm{Ho}, \mathrm{Zr} / \mathrm{Hf}$ and $\mathrm{Nb} / \mathrm{Ta}$ remains an intriguing problem in igneous geochemistry that awaits a fundamental explanation.

\section{Conclusions}

Heavy REE enrichment in Fe-rich clinopyroxenes from felsic magmas is caused by substitution into 6coordinated sites (M2 or M1). Increased heavy REE compatibility coincides with the higher Fe and Mn contents of these pyroxenes relative to more magnesian pyroxenes described elsewhere. This behavior can be modeled by summing the results for the two lattice strain model equations for 6-fold and 8-fold coordinated $3+$ cations with reasonable parameter values. Fractionation of $\mathrm{Y}$ from REE is observed in all three systems studied here and is not predicted by the lattice strain model. This feature cannot be explained by cation size differences, and may instead be a consequence of electronic effects or, as we speculate here, mass-dependent fractionation. If so, the same effect(s) may possibly play a role in the fractionation of $\mathrm{Zr}$ from $\mathrm{Hf}$, and of $\mathrm{Nb}$ from $\mathrm{Ta}$.

\section{Acknowledgements}

We would like to acknowledge Charles Knaack and Scott Cornelius of the Washington State University GeoAnalytical Laboratory for their assistance with ICP-MS and electron microprobe data collection. Early discussions with Else-Ragnhild Neumann were instrumental in initiating this study. We also thank Martin Streck for contributing Rattlesnake Tuff pyroxenes and glasses to this study. Fieldwork on Tenerife was funded by NSF grant EAR-0001013, and in the Jemez Mountains by NSF EAR-9909700. 


\section{References}

Andujar J, Costa F, Martí J, Wolff JA, Carroll MR (2008) Experimental constraints on pre-eruptive conditions of phonolitic magma from the caldera-forming El Abrigo eruption, Tenerife (Canary Islands). Chem Geol 257: 173-191

Bau M (1999) Scavenging of dissolved yttrium and rare earths by precipitating iron oxyhydroxide: Experimental evidence for Ce oxidation, Y-Ho fractionation, and lanthanide tetrad effect. Geochim Cosmochim Acta 63: 67-77

Bau M (1996) Controls on the fractionation of isovalent trace elements in magmatic and aqueous systes: evidence from Y/Ho, Zr/Hf, and lanthanide tetrad effect. Contrib Mineral Petrol 123: 323-333

Bau M, Dulski P (1999) Comparing yttrium and rare earths in hydrothermal fluids from the Mid-Atlantic Ridge: implications for $\mathrm{Y}$ and REE behaviour during near-vent mixing and for the $\mathrm{Y} / \mathrm{Ho}$ ratio of Proterozoic seawater. Chem Geol 155: 77-90

Bennett SL, Blundy J, Elliott T (2004) The effect of sodium and titanium on crystal-melt partitioning of trace elements. Geochim Cosmochim Acta 68: 2335-2347

Blundy J, Wood B (2003) Partitioning of trace elements between crystals and melts. Earth Planet Sci Lett 210: $383-397$

Blundy JD, Robinson JAC, Wood BJ (1998) Heavy REE are compatible in clinopyroxene on the spinel lherzolite solidus. Earth Planet Sci Lett 160: 493-504

Blundy J, Wood B (1994) Prediction of crystal-melt partition coefficients from elastic moduli. Nature 372 : $452-454$

Bottazzi P, Tiepolo M, Vannucci R, Zanetti A, Brumm R, Foley SF, Oberti R (1999) Distinct site preferences for heavy and light REE in amphibole and the prediction of ${ }^{\mathrm{Amph} / \mathrm{L}} \mathrm{D}_{\mathrm{REE}}$. Contrib Mineral Petrol 137: 36-45

Brice JC (1975) Some thermodynamic aspects of the growth of strained crystals. J Cryst Growth 28: 249253

Cameron M, Papike JJ (1980) Crystal chemistry of silicate pyroxenes. Reviews in Mineralogy 7: 5-92

Chacko T, Cole DR, Horita J (2001) Equilibrium oxygen, hydrogen and carbon isotope fractionation factors applicable to geologic systems. Reviews in Mineralogy and Geochemistry 43: 1-81 
Collerson KD, Williams Q, Murphy D (2007) Chemical and isotopic heterogeneities in the deep Earth; importance of lower mantle carbonate-rich melts. Eos Trans AGU 88: 52 Suppl

Droop GTR (1987) A general equation for estimating $\mathrm{Fe}^{3+}$ concentrations in ferromagnesian silicates and oxides from microprobe analyses, using stoichiometric criteria. Mineral Mag 51: 431-435

Edgar C, Wolff JA, Olin PH, Nichols, HJ, Pitarri A, Cas RAF, Reiners PW, Spell TL, Martí J (2007) The late Quaternary Diego Hernandez Formation, Tenerife: a cycle of repeated voluminous explosive phonolitic eruptions. J Volcanol Geotherm Res 160: 59-85

Fedele L, Zanetti A, Vincenzo M, Lustrino M, Melluso L, Vannucci R (2009) Clinopyroxene/liquid trace element partitioning in natural trachyte-trachyphonolite systems: insights from Campi Flegrei (southern Italy). Contrib Mineral Petrol (doi:10.1007/s00410-009-0386-5)

Foley SF, Tiepolo M, Vannucci R (2002) Trace element partitioning evidence for growth of early continental crust from amphibolites, not eclogites. Geochim Cosmochim Acta 66: 238

Gaetani GA, Grove TL (1995) Partitioning of rare earth elements between clinopyroxene and silicate melt; crystal chemical controls. Geochim Cosmochim Acta 59: 1951-1962

Green TH, Pearson NJ (1987) An experimental study of Nb and Ta partitioning between Ti-rich minerals and silicate liquids at high pressure and temperature. Geochim Cosmochim Acta 51: 55-62

Hamilton DL, MacKenzie WS (1965) Phase-equilibrium studies in the system $\mathrm{NaAlSiO}_{4}$ (nepheline) $\mathrm{KalSiO}_{4}$ (kalsilite) $-\mathrm{SiO}_{2}-\mathrm{H}_{2} \mathrm{O}$. Mineral Mag 34: 214-231

Hart SR, Dunn T (1993) Experimental cpx/melt partitioning of 24 trace elements. Contrib Mineral Petrol 113: $1-8$

Hauri EH, Wagner TP, Grove TL (1994) Experimental and natural partitioning of Th, U, Pb and other trace elements between garnet, clinopyroxene and basaltic melts. Chem Geol 117: 149-166

Hazen RM, Finger LW (1979) Bulk modulus-volume relationship for cation-anion polyhedra. J Geophys Res 84: 6723-6728

Hill E, Wood B, Blundy J (2000) The effect of Ca-Tschermaks component on trace element partitioning between clinopyroxene and silicate melt. Lithos 53: 203-215

Horng W, Hess PC (2000) Partition coefficients of Nb and Ta between rutile and anhydrous haplogranite melts. Contrib Mineral Petrol 138: 176-185 
Huang F, Lundstrom CC, McDonough WF (2006) Effect of the melt structure on trace-element partitioning between clinopyroxene and silicic, alkaline, aluminous melts. Am Mineral 91: 1385-1400

Irber W (1999) The lanthanide tetrad effect and its correlation with $\mathrm{K} / \mathrm{Rb}, \mathrm{Eu} / \mathrm{Eu}^{*}, \mathrm{Sr} / \mathrm{Eu}, \mathrm{Y} / \mathrm{Ho}$, and $\mathrm{Zr} / \mathrm{Hf}$ of evolving peraluminous granite suites. Geochim Cosmochim Acta 63: 489-508

Jaffe HW (1988) Crystal chemistry and refractivity. Cambridge University Press, Cambridge, p.118-140

Kuentz DC (1986) The Otowi Member of the Bandelier Tuff; a study of the petrology, petrography, and geochemistry of an explosive silicic eruption, Jemez Mountains, New Mexico. MSc thesis, University of Texas Arlington, USA.

Larsen LM (1979) Distribution of REE and other trace elements between phenocrysts and peralkaline undersaturated magmas, exemplified by rocks from the Gardar igneous province, south Greenland.

Lithos 12: 303-315

Lofgren GE, Huss GR, Wasserburg GJ (2006) An experimental study of trace-element partitioning between Ti-Al-clinopyroxene and melt: Equilibrium and kinetic effects including sector zoning. Am Mineral 91: 1596-1606

Lundstrom CC, Shaw HF, Ryerson FJ, Williams Q, Gill J (1998) Crystal chemical control of clinopyroxene-melt partitioning in the Di-Ab-An system: implications for elemental fractionations in the depleted mantle. Geochim Cosmochim Acta 62: 2849-2862.

Mahood GA, Stimac JA (1990) Trace-element partitioning in pantellerites and trachytes. Geochim Cosmochim Acta 54: 2275-2276

Min K, Reiners PW, Wolff JA, Mundil R, Winters RL (2006) (U-Th)/He dating of volcanic phenocrysts with high-U,Th inclusions, Bandelier Tuff, New Mexico. Chem Geol 227: 223-235

Nash WP, Crecraft HR (1985) Partition coefficients for trace elements in silicic magmas. Geochim Cosmochim Acta 49: 2309-2322

Niu Y (2004) Bulk-rock major and trace element compositions of abyssal peridotites: implications for mantle melting, melt extraction and post-melting processes beneath mid-ocean ridges. J Petrol 45: $2423-2458$

Niu Y, Hékinian R (1997) Basaltic liquids and harzburgitic residues in the Garrett Transform: a case study at fast-spreading ridges. Earth Planet Sci Lett 146: 243-258 
Nielsen RL, Beard JS (2000) Magnetite-melt partitioning. Chem Geol 164: 21-34

Oberti R, Vannucci R, Zanetti A, Tiepolo M, Brumm RC (2000) A crystal chemical re-evaluation of amphibole/melt and amphibole/clinopyroxene $\mathrm{D}_{\mathrm{Ti}}$ values in petrogenetic studies. Am Min 85: 407419

Olin PH (2007) Magma dynamics of the Diego Hernández Formation, Tenerife, Canary Islands. PhD thesis, Washington State Univ, USA, 416 pp.

Perterman M, Hirschmann MM (2002) Trace element partitioning between vacancy-rich clinopyroxene and silicate melts. Am Mineral 87: 1365-1376

Poldervaart A, Hess HH (1951) Pyroxenes in the crystallization of basaltic magma. J Geology 59: 472-489

Prowatke S, Klemme S (2005) Effect of melt composition on the partitioning of trace elements between titanite and silicate melt. Geochim Cosmochim Acta 69: 695-709

Robinson P (1980) The composition space of terrestrial pyroxenes - internal and external limits. Reviews in Mineralogy 7: 419-494

Rudnick RL, McDonough WF, Chappell BW (1993) Carbonatite metasomatism in the northern Tanzanian mantle; petrographic and geochemical characteristics. Earth Planet Sci Lett 114: 463-475

Schosnig M, Hoffer E (1998) Compositional dependence of REE partitioning between diopside and melt at 1 atmosphere. Contrib Mineral Petrol 133: 205-216

Shannon RD (1976) Revised effective ionic radii and systematic studies of interatomic distances in halides and chalcogenides. Acta Crystallogr A 32: 751-767

Shannon RD, Fischer RX (2006) Empirical electronic polarizabilities in oxides, hydroxides, oxyfluorides, and oxychlorides. Phys Rev B 73: 235111

Sisson TW (1991) Pyroxene-high silica rhyolites trace element partition coefficients measured by ion microprobe. Geochim Cosmochim Acta 55: 1575-1585

Spell TL, Kyle PR, Thirwall MF, Campbell AR (1990) Nd, Sr, and O isotopic geochemistry of postcollapse rhyolites in the Valles Caldera, New Mexico. Eos Trans AGU 71: 1676

Streck MJ, Grunder AL (1997) Compositional gradients and gaps in high-silica rhyolites of the Rattlesnake Tuff, Oregon. J Petrol 38: 133-163 
Streck MJ, Grunder AL (2007) Phenocryst-poor rhyolites of bimodal, tholeiitic provinces: the Rattlesnake Tuff and implications for mush extraction models. Bull Volcanol 70: 385-401

Stimac J, Hickmott D (1994) Trace-element partition coefficients for ilmenite, orthopyroxene and pyrrhotite in rhyolite determined by micro-PIXE analysis. Chem Geol 117: 313-330

Thompson RN, Morrison MA, Hendry GL, Parry SJ (1984) An assessment of the relative roles of crust and mantle in magma genesis: an elemental approach. Phil Trans R Soc London A 310: 549-590

Tiepolo M, Oberti R, Vannucci R (2002) Trace-element incorporation in titanite: constraints from experimentally determined solid/liquid partition coefficients. Chem Geol 191: 105-119

Tuttle OF, Bowen NL (1958) Origin of granite in the light of experimental studies in the system NaAlSi3O8-KAlSi3O8-SiO2-H2O. Geol Soc Amer Memoir 74.

Vannucci R, Bottazzi P, Wulff-Pedersen E, Neumann E-R (1998) Partitioning of REE, Y, Sr, Zr and Ti between clinopyroxene and silicate melts in the mantle under La Palma (Canary Islands): implications for the nature of the metasomatic agents. Earth Planet Sci Lett 158: 39-51

Wade J, Wood BJ (2001) The Earth's ‘missing' Nb may be in the core. Nature 409: 75-78

Warshaw CM, Smith RL (1988) Pyroxenes and fayalites in the Bandelier Tuff, New Mexico: Temperatures and comparisons with other rhyolites. Am Mineral 73: 1025-1037

Wolff JA (1984) Variation in $\mathrm{Nb} / \mathrm{Ta}$ during differentiation of phonolitic magma, Tenerife, Canary Islands. Geochim Cosmochim Acta 48: 1345-1348

Wolff JA, Grandy JS, Larson PB (2000) Interaction of mantle-derived magma with island crust? Trace element and oxygen isotope data from the Diego Hernandez Formation, Las Cañadas, Tenerife. J Volcanol Geotherm Res 103: 343-366

Wolff JA, Ramos FC, Davidson JP (1999) Sr isotope disequilibrium during differentiation of the Bandelier Tuff; constraints on the crystallization of a large rhyolitic magma chamber. Geology 27: 495-498

Wolff JA, Storey M (1984) Zoning in highly alkaline magma bodies. Geol Mag 121: 563-575

Wolff JA, Storey M (1983) The volatile component of some pumice-forming alkaline magmas from the Azores and Canary Islands. Contrib Mineral Petrol 82: 66-74

Wood BJ, Blundy JD (2002) The effect of H2O on crystal-melt partitioning of trace elements. Geochim Cosmochim Acta 66: 3647-3656 
Wood B, Blundy J (2001) The effect of cation charge on crystal-melt partitioning of trace elements. Earth Planet Sci Lett 188: 59-71

Wood B, Blundy J (1997) A predictive model for rare earth element partitioning between clinopyroxene and anhydrous silicate melt. Contrib Mineral Petrol 129: 166-181

Wood B, Trigila R (2001) Experimental determination of aluminous clinopyoxene-melt partition coefficients for potassic liquids, with application to the evolution of the Roman province potassic magmas. Chem Geol 172: 213-223

Wörner G, Beusen JM, Duchateau N, Gijbels R, Schmincke H-U (1983) Trace element abundances and mineral/melt distribution coefficients in phonolites from the Laacher See Volcano (Germany). Contrib Mineral Petrol 84: 152-173 


\section{Figure captions}

Figure 1: Clinopyroxene-melt REE partition coefficients versus atomic number of pyroxenes from the literature and from this study. Literature data are from pyroxenes in alkali basalt (Hart and Dunn, 1993; Mg\# 55.2; black triangles), lherzolite (Blundy et al., 1998; Mg\# 83.7; black diamonds), phonolite (Wörner et al., 1983; Mg\# 65.6; black circles), phonolite (Larsen, 1979; Mg\# 25.3; black squares), pantellerite (Mahood and Stimac, 1990; Mg\# 18.3; open triangles), trachyphonolite (Fedele et al., 2009; Mg\# 67; open circles), high-silica rhyolite (Sisson, 1991; Mg\# 16.8; open squares), rhyolite (Nash and Crecraft, 1985; Mg\# 41.7; dashed x). Data from this study; average Na-salite in Fasnia Member phonolite (Mg\# 48 to 59; red), average ferroaugite/ferrohedenbergite in Rattlesnake Tuff rhyolite (Mg\# 9.6 to 32; solid black), average ferroaugite/ferrohedenbergite in Bandelier Tuff high-silica rhyolite (Mg\# 14.2 to 16.2; blue).

Figure 2: Pyroxene quadrilateral showing Tenerife Na-salites (FM), Rattlesnake Tuff (RT) ferrohedenbergites to ferroaugites, and Bandelier Tuff (BT) ferrohedenbergites. Pyroxene quadrilateral after Poldervaart and Hess, 1951.

Figure 3: Rare earth elements contents of average pyroxene (solid symbols) and glass (open symbols) compositions for FM (red), RT (black), and BT (blue) normalized to Bulk Silicate Earth, McDonough \& Sun, 1995. For comparison, values determined for standard materials BCR (gray) and in-house pyroxene (TFPX, black) are also shown for laser ablation (solid, no symbols) and solution (dashed, no symbols) methods.

Figure 4: Covariations of selected minor and trace elements and ratios in the pyroxenes.

Figure 5: Lattice strain model plotted (a) as $\log$ (partition coefficient) versus ionic radius for idealized elements of the same valence state and same coordination number, where $D_{0}$ is the partition coefficient for the optimal ionic radius $r_{0}$, and $E_{\mathrm{M}}$ is the Young's modulus for the site, (b) showing $\mathrm{REE}^{3+}$ partition coefficient distribution for six-fold and eightfold coordination in pyroxene, and (c) shows equation (2), the linear expression of model equation. Samples shown in (c) have the best $R^{2}$ values from each of the three populations (FM red, RT black, BT blue), for elements La through Dy in eight-fold coordination (see text for details).

Figure 6: Calculated REE partition coefficient ranges for FM, RT, and BT pyroxenes.

Figure 7: Model curves for REE ${ }^{3+}$ cations for FM (a), RT (b), and BT (c) pyroxenes. The model curves are for elements in six-fold (red, squares) and eight-fold (blue, diamonds) coordination and the sum of the two curves (solid black, triangles). The average composition for each population is also shown (black dashed, gray $\mathrm{x}$ ), but is obscured by the model curves. Note that the negative Y partition coefficient anomaly that is especially prominent in average RT and BT hedenbergites, and in other iron-rich pyroxenes in Figure 1, is not predicted by the model (see text for details). 
Figure 8: Partition coefficient co-variation and ratio plots for selected trace elements.

Figure 9: $\mathrm{D}_{\mathrm{Lu}}$ versus $\mathrm{Fe}^{2+}$ and $\mathrm{Mn}$ contents of the pyroxenes. BT samples are omitted from this plot because trace element analyses do not correspond to locations for major element determinations. 


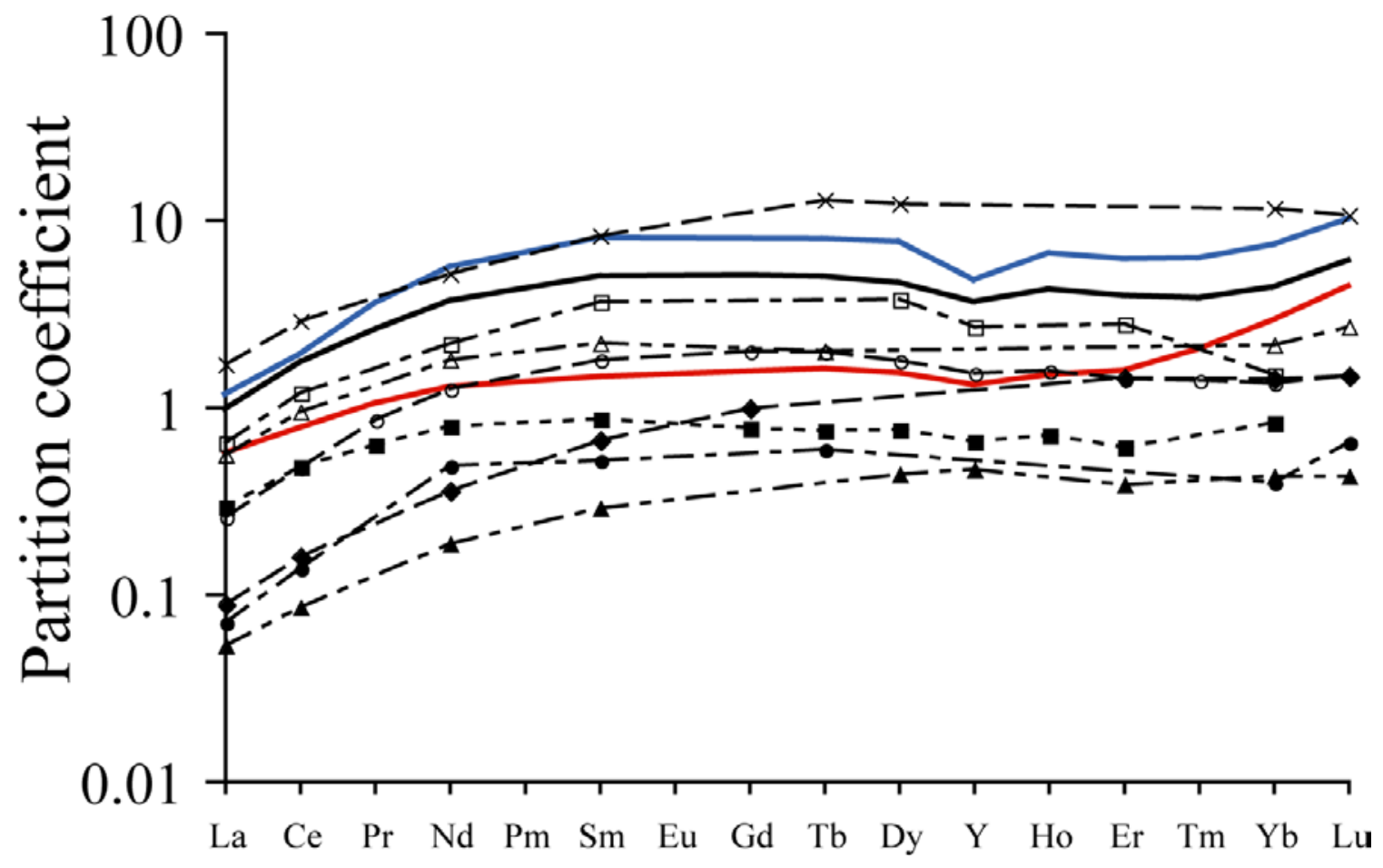

Figure 1 


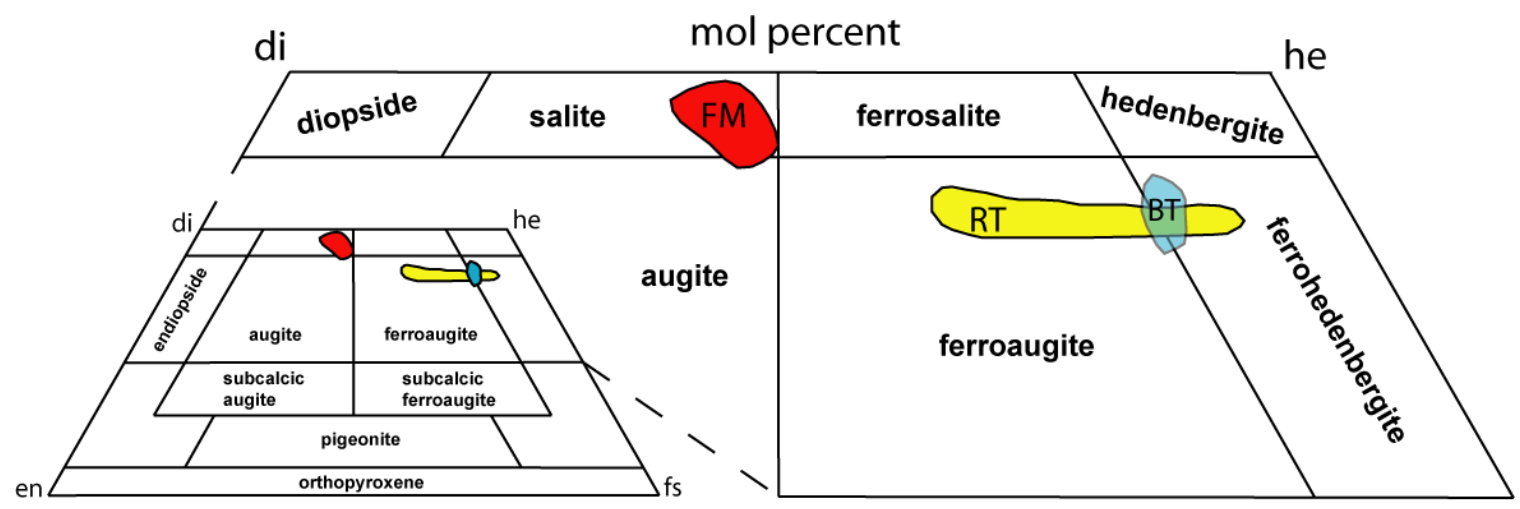

Figure 2 


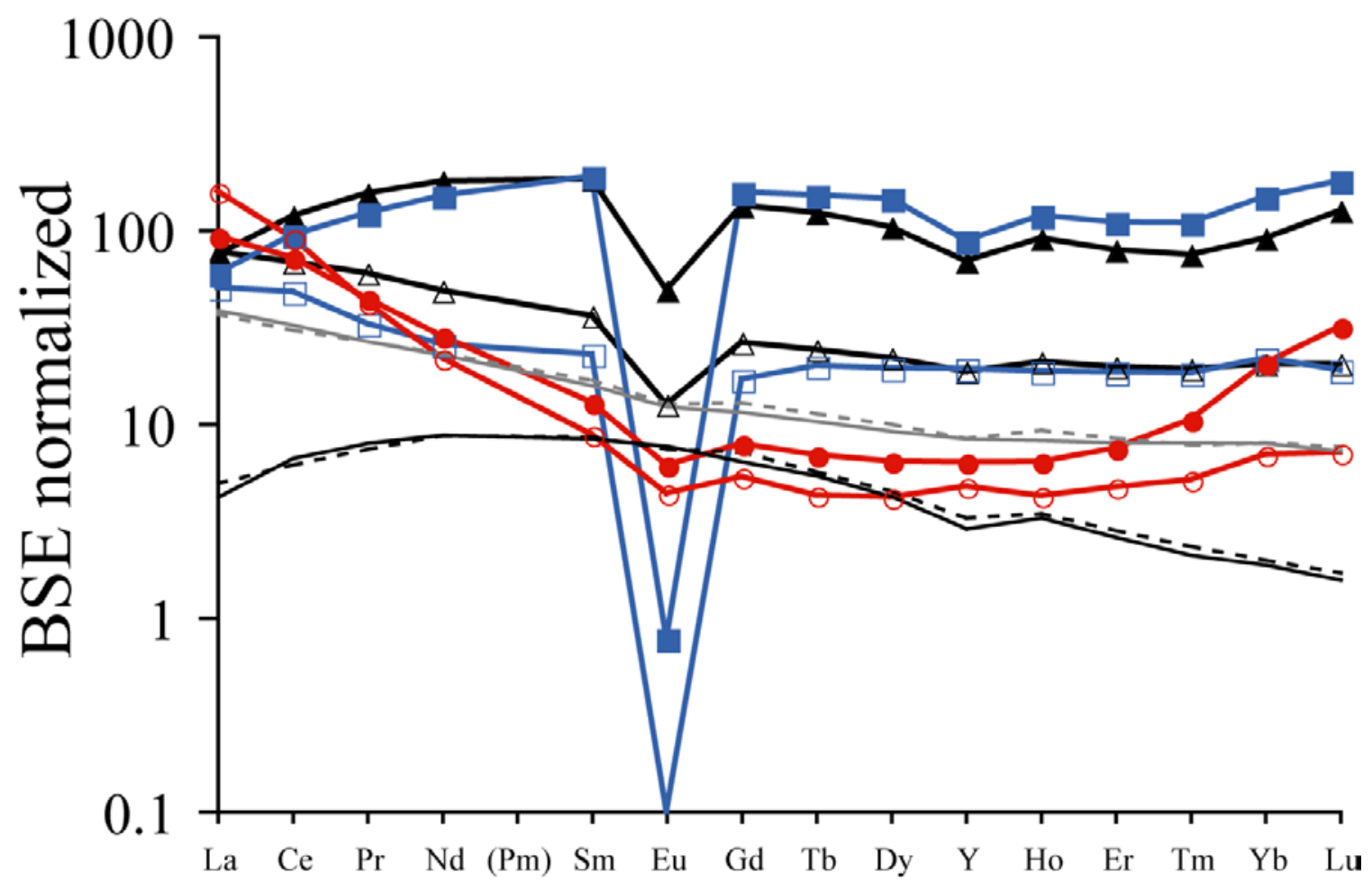

Figure 3 

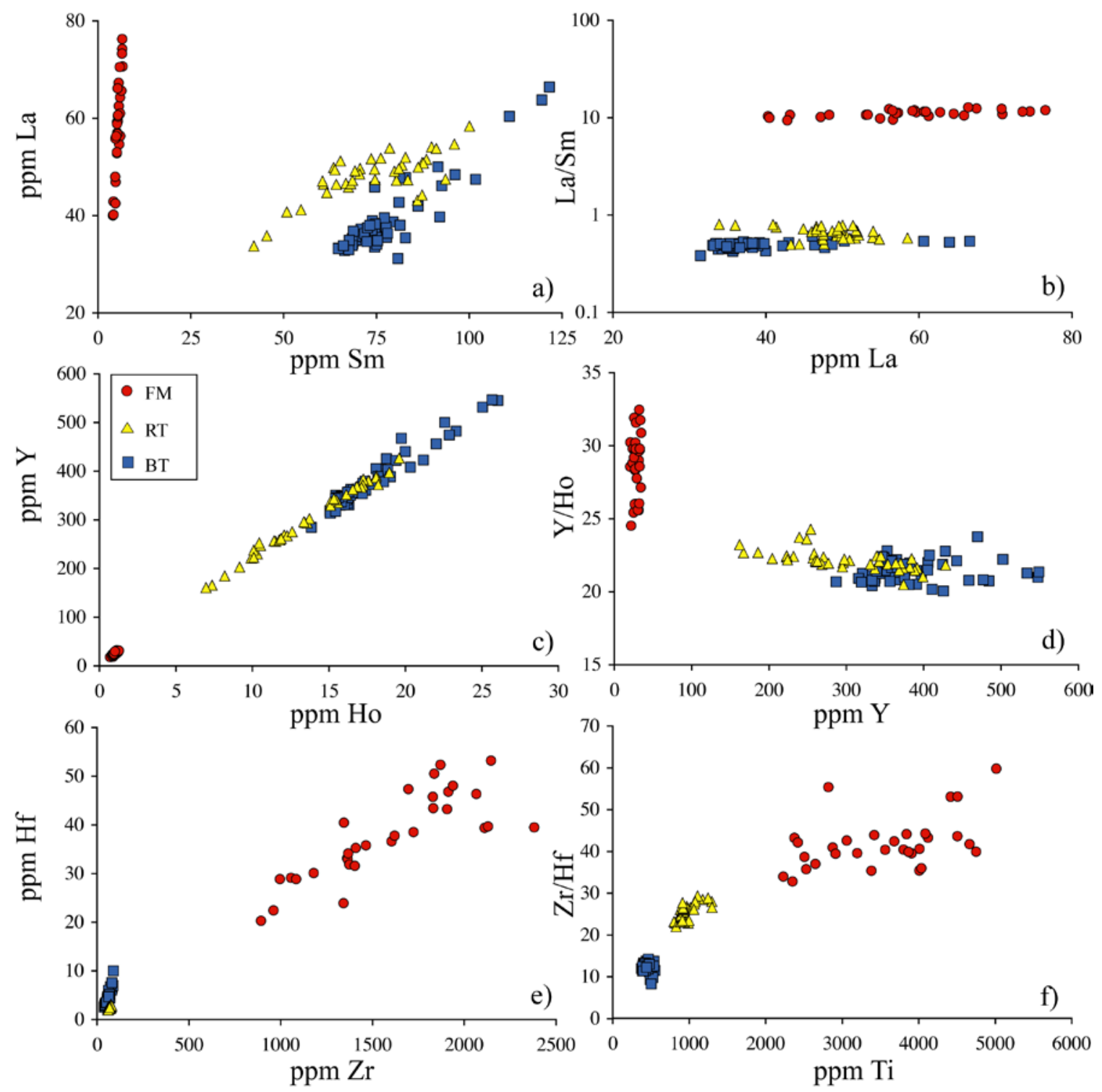

Figure 4 

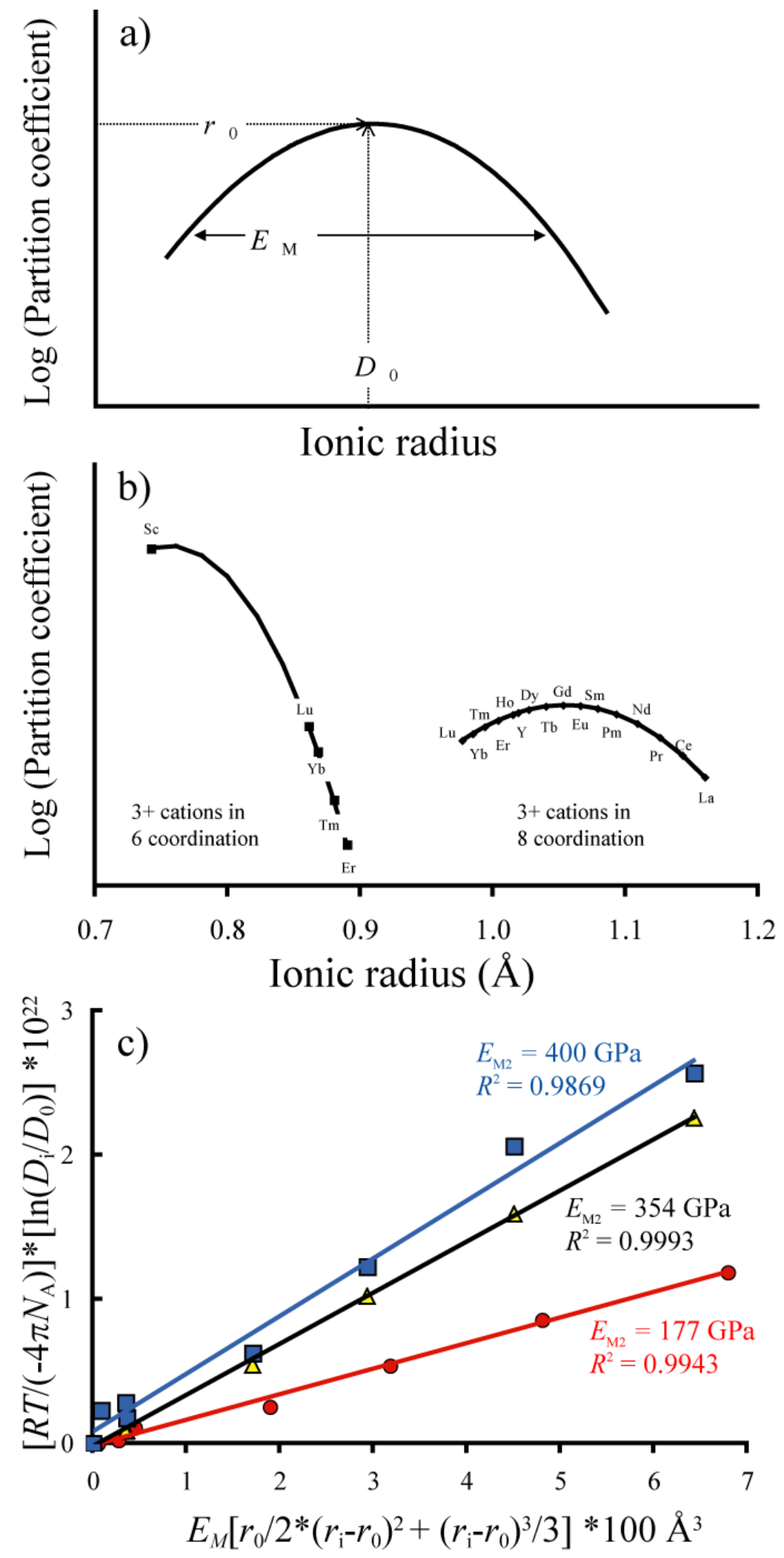

Figure 5 
This is an author-produced, peer-reviewed version of this article. The final publication is available at www.springerlink.com. Copyright restrictions may apply. DOI: 10.1007/s00410-010-0506-2

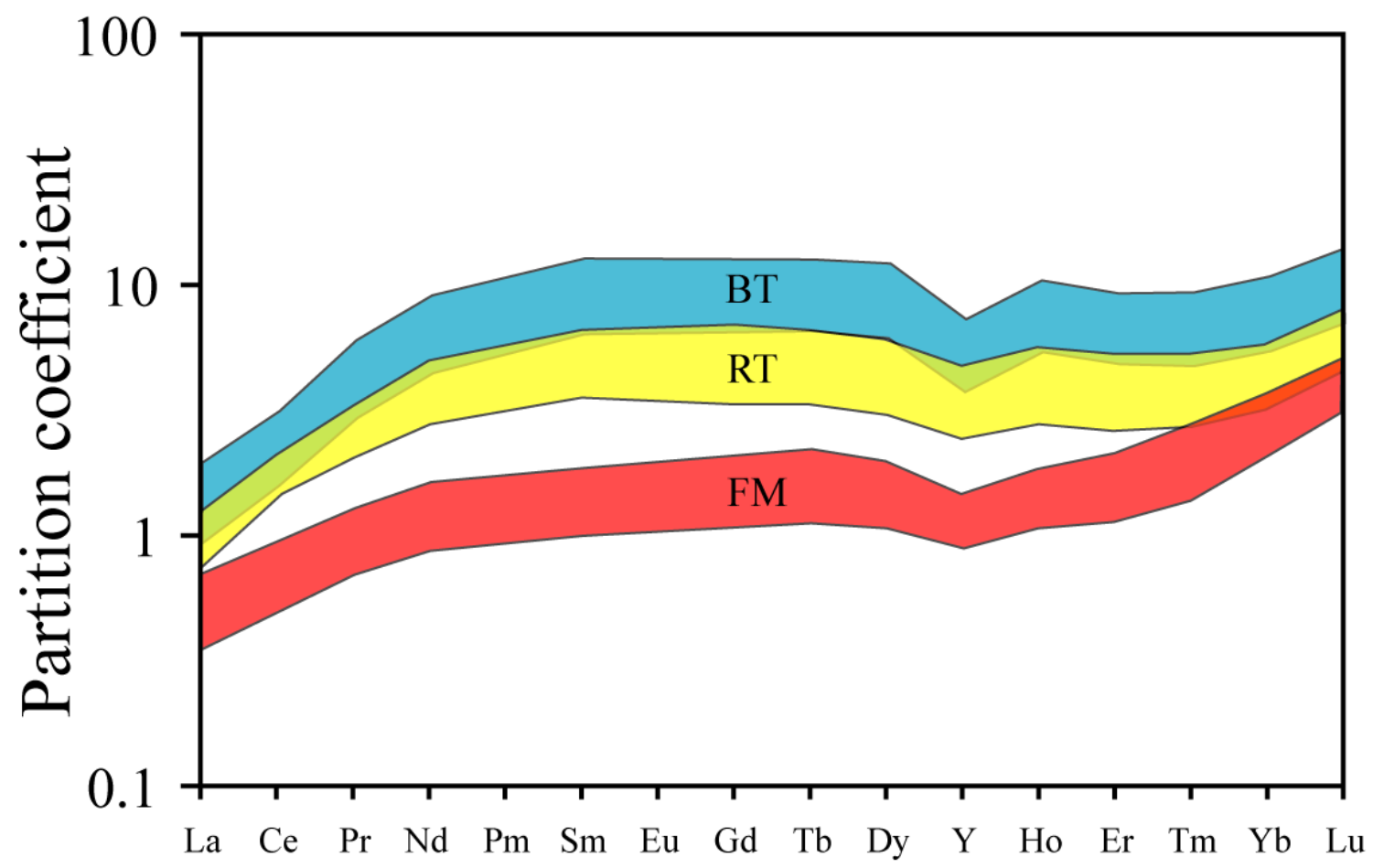

Figure 6 

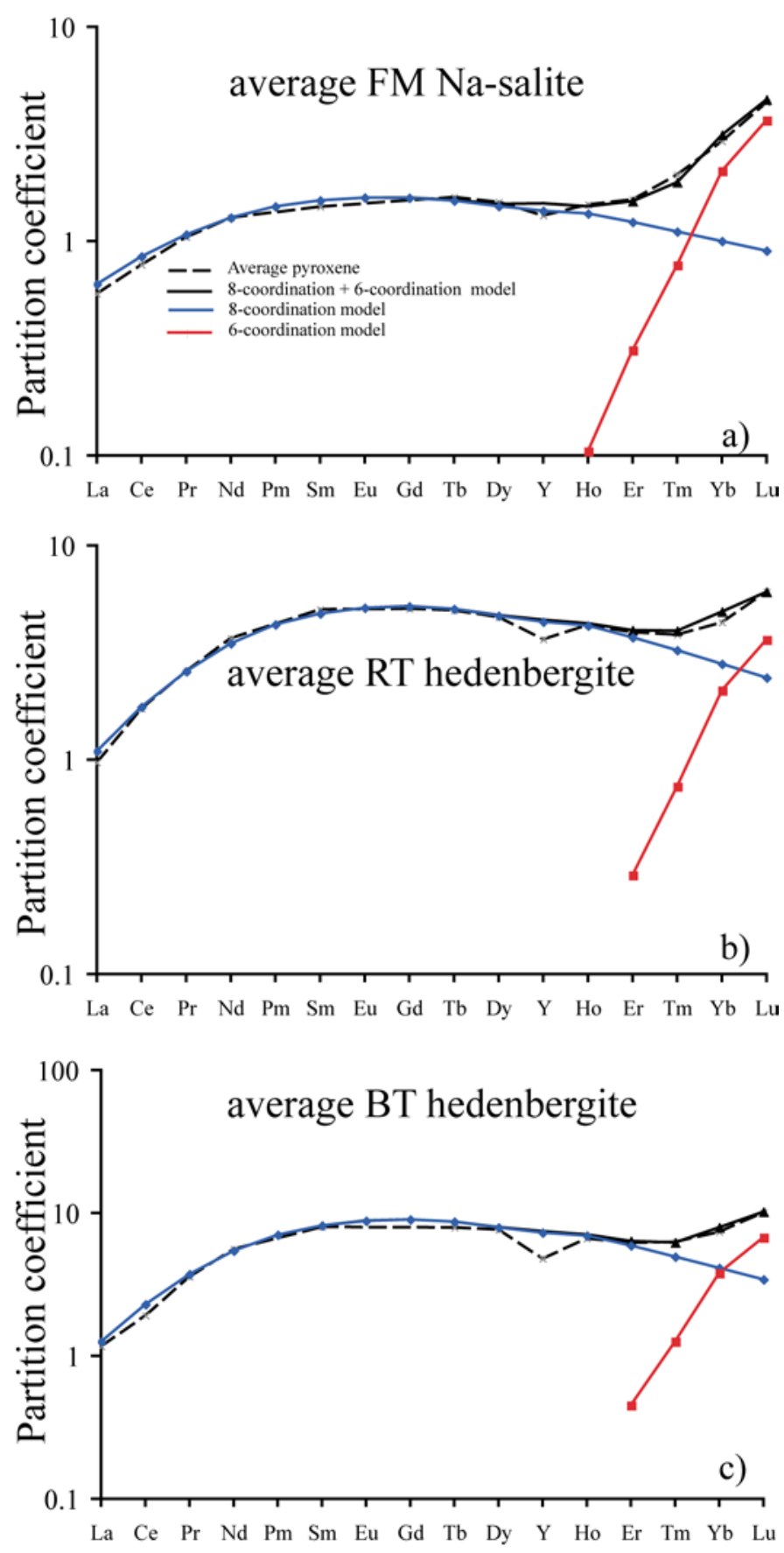

Figure 7 

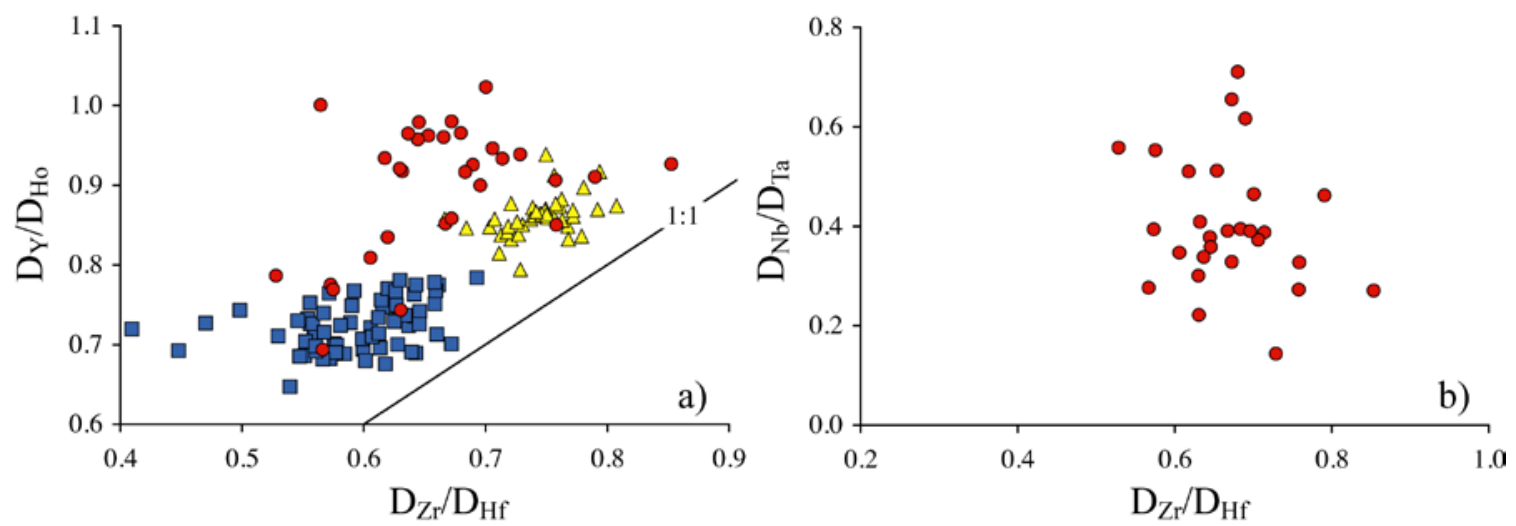

Figure 8 

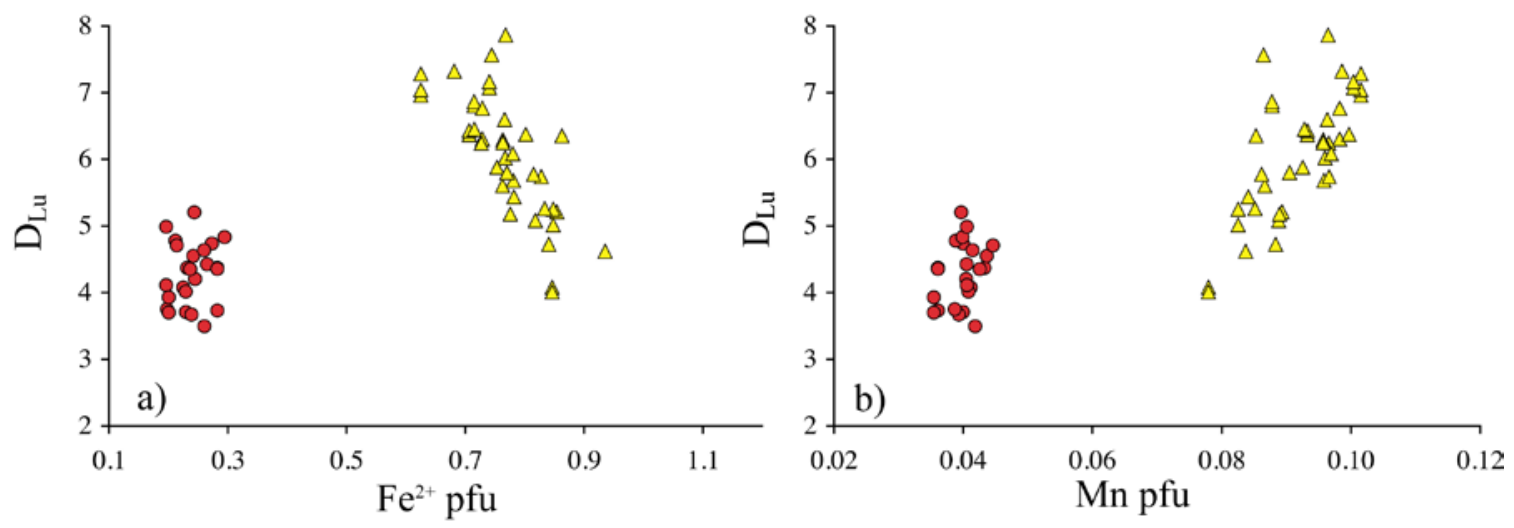

Figure 9 


\section{Table captions}

Table 1. Characteristics of the three felsic volcanic units analyzed in this study.

Table 2: Representative major and trace element contents of FM, RT and BT pyroxenes and glasses. BT pyroxene major element and trace element values are from different grains.

Table 3: Ionic radii for major and trace element cations in eight- and six-fold coordination, from Shannon (1976).

Table 4: Values for lattice strain model parameters used to generate model curves in Figure 7.

Table 5: Pyroxene-glass partition coefficients; maximum, minimum, average, and model curve values.

Table 6: Electronic polarizability, $\alpha$, of Y, HREE, and HFSE cations, from Shannon and Fischer (2006). $\Delta=\left[\alpha_{\text {(light ion) }}-\alpha_{\text {(heavy ion) }}\right] / \alpha_{\text {(light ion) }}$ 


\section{Table 1}

Volcano or province

Age, Ma

Magma

volume, $\mathrm{km}^{3}$

Magma

composition

Phenocryst

assemblage

Melt silica

saturation

Melt

$(\mathrm{Na}+\mathrm{K}) / \mathrm{Al}$

Melt

$\mathrm{NBO} / \mathrm{T} * *$

Magma T, ${ }^{\circ} \mathrm{C}$

Pressure, kbar

$\mathrm{fO}_{2}$

Pyroxene

composition
Fasnia Member (FM) ${ }^{1}$

Las Cañadas, Tenerife,

Canary Islands, Spain

0.309

13

Minimum-melt

phonolite

Sodic sanidine + haüyne +

clinopyroxene + biotite

+ titanite + magnetite

$$
n e=27 \%
$$

$0.99 \pm 0.02$

0.26

825

1

NNO

Na-salite

$48-58$
Otowi Member of the

Bandelier Tuff (BT) ${ }^{2}$

Valles caldera, New

Mexico, USA

1.61

$\sim 120^{*}$

Minimum-melt high-

silica rhyolite

Sodic sanidine + quartz

+ clinopyroxene +

magnetite + fayalite

$$
Q=33 \%
$$

$1.02 \pm 0.03$

0.25

700

1.5

QMF

Ferrohedenbergite

$14.2-16.2$
Rattlesnake Tuff $(\mathrm{RT})^{3}$

High Lava Plains, eastern Oregon, USA

7.05

280

Rhyolite, 75 - 77

wt. $\% \mathrm{SiO}_{2}$

Alkali feldspar + quartz +

clinopyroxene \pm fayalite

$Q=30-35 \%$

$1.00-1.03$

$0.24-0.25$

800

1

$\sim$ QMF

Ferroaugite ferrohedenbergite

$9.6-31.7$

References: ${ }^{1}$ Edgar et al. (2007); ${ }^{2}$ Warshaw \& Smith (1988), Spell et al. (1996); ${ }^{3}$ Streck \& Grunder (1997).

*The BT pyroxenes and glasses in this study are taken from the first $120 \mathrm{~km}^{3}$ of homogeneous magma ejected during the Otowi Member eruption. The total volume for the unit is $\sim 450 \mathrm{~km}^{3}$.

$* * \mathrm{NBO} / \mathrm{T}=(2 \mathrm{O}+4 \mathrm{~T}) / \mathrm{T}$, where $\mathrm{O}=$ total oxygen atoms and $\mathrm{T}=\left(\mathrm{Si}+\mathrm{Al}+\mathrm{Fe}^{3+}+\mathrm{Ti}\right)$ on a molar basis, and assuming 3\% dissociated $\mathrm{H}_{2} \mathrm{O}$, corresponding to total magmatic water contents of 5\% in each case (Sowerby \& Keppler, 1999). 

www.springerlink.com. Copyright restrictions may apply. DOI: 10.1007/s00410-010-0506-2

\begin{tabular}{|c|c|c|c|c|c|c|c|c|c|}
\hline Table 2 & $\begin{array}{l}\text { FM phon. } \\
\text { glass }\end{array}$ & $\begin{array}{l}\text { FM } \\
\text { Na-salite }\end{array}$ & $\begin{array}{l}\text { FM } \\
\text { Na-salite }\end{array}$ & $\begin{array}{l}\text { RT rhyo. } \\
\text { glass }\end{array}$ & $\begin{array}{l}\text { RT } \\
\text { ferroaug/hed }\end{array}$ & $\begin{array}{l}\text { RT } \\
\text { ferroaug/hed }\end{array}$ & $\begin{array}{l}\text { BT rhyo. } \\
\text { glass }\end{array}$ & $\begin{array}{l}\text { BT } \\
\text { ferrohed/aug }\end{array}$ & $\begin{array}{l}\text { BT } \\
\text { ferrohed/aug }\end{array}$ \\
\hline Oxide & 03TF16 & 99TF6gmB_PX2B & $0154 \mathrm{px} 1$ & RT173C & RT173B_lb & RT173C_4a & 0086A & $13 / 2 \_a$ & $13 / 3$ \\
\hline $\mathrm{SiO}_{2}$ & 58.58 & 49.21 & 48.72 & 75.47 & 48.06 & 47.76 & 77.17 & 48.66 & 48.74 \\
\hline $\mathrm{TiO}_{2}$ & 0.43 & 0.87 & 0.69 & 0.16 & 0.21 & 0.30 & 0.04 & 0.07 & 0.12 \\
\hline $\mathrm{Al}_{2} \mathrm{O}_{3}$ & 21.58 & 2.49 & 2.11 & 12.26 & 0.41 & 0.54 & 12.09 & 0.38 & 0.30 \\
\hline $\mathrm{FeO}$ & 2.31 & 15.27 & 13.43 & 1.96 & 25.33 & 28.85 & 1.29 & 26.14 & 26.11 \\
\hline $\mathrm{MnO}$ & 0.19 & 1.35 & 1.23 & 0.10 & 2.76 & 2.39 & 0.10 & 2.77 & 2.89 \\
\hline $\mathrm{MgO}$ & 0.24 & 7.98 & 8.54 & 0.01 & 3.71 & 1.73 & 0.02 & 2.72 & 2.44 \\
\hline $\mathrm{CaO}$ & 0.82 & 20.24 & 20.46 & 0.50 & 17.99 & 17.61 & 0.25 & 17.99 & 18.14 \\
\hline $\mathrm{Na}_{2} \mathrm{O}$ & 8.80 & 2.30 & 2.23 & 4.61 & 0.54 & 0.45 & 4.69 & 0.74 & 0.68 \\
\hline $\mathrm{K}_{2} \mathrm{O}$ & 5.84 & & & 4.69 & & & 4.35 & & \\
\hline Totals & 98.79 & 99.76 & 97.42 & 99.4 & 99.08 & 99.67 & & 99.47 & 99.42 \\
\hline \multicolumn{10}{|l|}{ Cations } \\
\hline $\mathrm{Si}$ & & 1.88 & 1.89 & & 1.96 & 1.97 & & 1.98 & 2.00 \\
\hline $\mathrm{Al}$ & & 0.11 & 0.10 & & 0.02 & 0.03 & & 0.02 & 0.01 \\
\hline $\mathrm{Na}$ & & 0.17 & 0.17 & & 0.04 & 0.04 & & 0.06 & 0.05 \\
\hline $\mathrm{Ca}$ & & 0.83 & 0.85 & & 0.79 & 0.78 & & 0.79 & 0.79 \\
\hline $\mathrm{Mn}$ & & 0.04 & 0.04 & & 0.10 & 0.08 & & 0.09 & 0.10 \\
\hline $\mathrm{Fe}^{2+}$ & & 0.24 & 0.19 & & 0.77 & 0.93 & & 0.84 & 0.87 \\
\hline $\mathrm{Fe}^{3+}$ & & 0.25 & 0.24 & & 0.10 & 0.06 & & 0.05 & 0.02 \\
\hline $\mathrm{Mg}$ & & 0.45 & 0.49 & & 0.23 & 0.11 & & 0.17 & 0.15 \\
\hline $\mathrm{Ti}$ & & 0.02 & 0.02 & & 0.01 & 0.01 & & 0.00 & 0.00 \\
\hline Cation total & & 4.00 & 4.00 & & 4.00 & 4.00 & & 4.00 & 4.00 \\
\hline \multicolumn{10}{|c|}{ Trace elements } \\
\hline ppm Sc & b.d.l. & 27 & 30 & 3.3 & 412 & 357 & b.d.l. & 155 & 60 \\
\hline $\mathrm{Sr}$ & 33 & 3.8 & 3.7 & 18 & 3.9 & 11 & 0.1 & 0.08 & 0.05 \\
\hline $\mathrm{Y}$ & 21 & 26 & 31 & 76 & 270 & 185 & 78 & 286 & 548 \\
\hline $\mathrm{Zr}$ & 1393 & 1,363 & 2,062 & 350 & 64 & 77 & 204 & 35 & 86 \\
\hline $\mathrm{Nb}$ & 239 & 2.8 & 3.0 & 25 & 0.09 & 0.09 & 185 & 0.31 & 0.90 \\
\hline $\mathrm{Ba}$ & 88 & 0.43 & 0.36 & 1685 & 0.84 & 0.68 & 0.17 & 0.33 & 0.86 \\
\hline $\mathrm{La}$ & 101 & 57 & 61 & 50 & 50 & 41 & 33 & 33 & $6 ?$ \\
\hline $\mathrm{Ce}$ & 136 & 118 & 133 & 114 & 203 & 169 & 84 & 132 & 257 \\
\hline Pr & 10 & 10.9 & 12.5 & 15 & 40 & 31 & 9.0 & 26 & 45 \\
\hline $\mathrm{Nd}$ & 26 & 34 & 40 & 61 & 222 & 169 & 34 & 161 & 30 \\
\hline $\mathrm{Sm}$ & 3.6 & 5.0 & 5.8 & 14 & 71 & 51 & 10 & 66 & 121 \\
\hline $\mathrm{Eu}$ & 0.64 & 0.91 & 1.00 & 2.3 & 7.5 & 7.3 & b.d.l. & 0.16 & 0.21 \\
\hline $\mathrm{Gd}$ & n.d. & 3.9 & 5.3 & n.d. & 67 & 46 & n.d. & 72 & 134 \\
\hline $\mathrm{Tb}$ & 0.40 & 0.67 & 0.82 & 2.2 & 11 & 7.5 & 1.9 & 12 & 22 \\
\hline Dy & 2.8 & 4.1 & 5.3 & 14 & 62 & 42 & 13 & 78 & 14 \\
\hline Но & 0.68 & 0.91 & 1.20 & 2.9 & 12 & 8.2 & 2.7 & 14 & 26 \\
\hline Er & 2.3 & 3.0 & 4.2 & 8.1 & 31 & 22 & 8.0 & 36 & 67 \\
\hline $\mathrm{Tm}$ & 0.38 & 0.66 & 0.95 & 1.2 & 4.7 & 3.4 & 1.2 & 5.3 & 10 \\
\hline $\mathrm{Yb}$ & 3.3 & 8.0 & 11.0 & 8.0 & 35 & 26 & 8.5 & 41 & 81 \\
\hline $\mathrm{Lu}$ & 0.53 & 1.9 & 2.8 & 1.3 & 7.9 & 6.1 & 1.2 & 7.9 & 16 \\
\hline $\mathrm{Hf}$ & 23 & 34 & 47 & 9.4 & 2.4 & 2.9 & 10 & 2.7 & 10 \\
\hline $\mathrm{Ta}$ & 7.0 & 0.19 & 0.34 & 1.5 & b.d.l. & b.d.l. & 11 & b.d.l. & b.d.l \\
\hline $\mathrm{Pb}$ & 22 & 0.54 & 0.41 & 13 & 0.72 & 0.59 & 35 & 1.3 & 2.2 \\
\hline Th & 42 & 0.09 & 0.12 & 5.6 & 0.02 & 0.02 & 34 & 0.03 & 0.13 \\
\hline $\mathrm{U}$ & 12 & 0.01 & 0.01 & 2.9 & 0.00 & 0.01 & 18 & 0.01 & 0.02 \\
\hline
\end{tabular}


Table 3

Cation

VIII-fold VI-fold

ionic radius ionic radius

$\mathrm{Na} 1+$

(A)

(A)

$\mathrm{Ca} 2+$

1.18

$\mathrm{Mn} 2+$

1.12

Fe $2+$

0.83

Mg 2+

0.78

Ti 4+

0.72

La $3+$

1.16

0.605

Ce 3+

1.143

1.032

Pr 3+

1.126

1.010

Nd 3+

1.109

0.990

Pm 3+

1.093

0.983

Sm 3+

1.079

0.970

Eu 3+

1.066

0.958

Gd 3+

1.053

0.947

Tb 3+

1.04

0.938

Dy $3+$

1.027

0.923

Y 3+

1.019

0.912

Ho 3+

1.015

0.900

Er 3+

1.004

0.901

Tm 3+

0.994

0.890

$\mathrm{Yb} 3+$

0.985

0.880

Lu 3+

0.977

0.868

Sc 3+

0.861

Zr 4+

0.745

Hf 4+

0.72

$\mathrm{Nb} 5+$

0.71

0.64

Ta 5+

0.64 


\section{Table 4}

Model Values

$T^{\circ} \mathrm{C}$

${ }^{\mathrm{VIIII}} \mathrm{E}^{3+}{ }_{\mathrm{M} 2} \mathrm{GPa}$

${ }^{\mathrm{VIII}} r_{0} \AA$

VIII $D_{0}$

${ }^{\mathrm{VI}} E^{3+}{ }_{\mathrm{M}} \mathrm{GPa}$

${ }^{\mathrm{VI}} r_{0} \AA$

${ }^{\mathrm{VI}} \mathrm{D}_{0}$

\section{FM Na-salites}

825

177

1.060

1.6

775

0.724

500

\section{RT ferroaugites}

800

296

1.055

5.2

1000

0.758

150
BT ferrohedenbergites

700

339

1.055

9.0

1100

0.772

200 
This is an author-produced, peer-reviewed version of this article. The final publication is available at www.springerlink.com. Copyright restrictions may apply. DOI: 10.1007/s00410-010-0506-2

Table 5

FM Na-salites

$(n=31)$

\begin{tabular}{|c|c|c|c|}
\hline Element & Max & Min & Ave \\
\hline Sc & n.d. & n.d. & n.d \\
\hline $\mathbf{T i}$ & 1.9 & 0.8 & 1. \\
\hline $\mathbf{Y}$ & 1.5 & 0.9 & \\
\hline $\mathrm{Zr}$ & 1.7 & 0.7 & 1. \\
\hline Nb & 0.04 & 0.01 & 0.02 \\
\hline La & 0.7 & 0.4 & 0 \\
\hline Ce & 1.1 & 0.5 & 0. \\
\hline Pr & 1.5 & 0.7 & 1 \\
\hline Nd & 2.2 & 0.9 & 1. \\
\hline Sm & 2.4 & 1.0 & 1. \\
\hline Eu & 2.6 & 1.0 & 1. \\
\hline Gd & n.d. & n.d. & n.c \\
\hline Tb & 2.2 & 1.2 & 1. \\
\hline Dy & 2.1 & 1.1 & 1. \\
\hline Ho & 2.2 & 1.1 & 1. \\
\hline Er & 2.1 & 1.2 & 1. \\
\hline Tm & 2.8 & 1.5 & 2. \\
\hline $\mathbf{Y b}$ & 3.6 & 2.4 & 2. \\
\hline Lu & 5.9 & 3.5 & 4. \\
\hline Hf & 2.6 & 1.0 & 1. \\
\hline Ta & 0.16 & 0.01 & 0.0 \\
\hline
\end{tabular}

Pyroxene - Glass Partition Coefficients

RT ferroaug/hed

$(n=40)$

Model Max

n.d. 186

n.d. 2.0

$1.5 \quad 4.8$

n.d. $\quad 0.3$

n.d. $\quad 0.005$

$0.6 \quad 1.2$

$0.8 \quad 2.0$

$\begin{array}{ll}1.0 & 3.3\end{array}$

$1.3 \quad 4.9$

$1.5 \quad 6.6$

$1.6 \quad 7.6$

1.6

1.6

1.5

1.5

1.5

1.9

3.1

4.6

n.d.

n.d.

Min
93
1.2
2.1
0.2
0.002
0.7
1.2
1.7
2.3
2.9
5.6
n.d.
2.8
2.6
2.4
2.3
2.3
2.8
4.0
0.2
n.d.

Min

Ave

143

1.5

3.6

0.2

0.003

1.0

1.7

2.6

3.7

5.0

6.5

n.d.

5.0

4.6

4.2

3.9

3.8

4.4

6.1

0.3

n.d.
BT ferrohed/aug

$(n=67)$

Model Max

139 n.d.

n.d. $\quad 2.0$

$4.5 \quad 7.2$

n.d. $\quad 0.4$

n.d. $\quad 0.019$

$1.1 \quad 2.3$

$\begin{array}{ll}1.8 & 3.9\end{array}$

2.6

3.5

4.8

5.1

5.2

5.1

4.7

4.3

4.0

4.0

4.9

6.1

n.d.

n.d.

$\begin{array}{rrr}\text { Min } & \text { Ave } & \text { Model } \\ \text { n.d. } & \text { n.d. } & \text { n.d. } \\ 1.3 & 1.6 & \text { n.d. } \\ 3.8 & 4.8 & 7.4 \\ 0.2 & 0.3 & \text { n.d. } \\ 0.001 & 0.004 & \text { n.d. } \\ 0.9 & 1.2 & 1.3 \\ 1.5 & 1.9 & 2.3 \\ 2.9 & 3.6 & 3.7 \\ 4.4 & 5.6 & 5.4 \\ 6.3 & 8.0 & 8.2 \\ \text { n.d. } & \text { n.d. } & 8.8 \\ \text { n.d. } & \text { n.d. } & 9.0 \\ 6.6 & 7.9 & 8.7 \\ 6.1 & 7.6 & 7.9 \\ 5.5 & 6.6 & 7.0 \\ 4.9 & 6.2 & 6.4 \\ 4.8 & 6.3 & 6.2 \\ 5.4 & 7.4 & 7.9 \\ 7.2 & 10 & 9.8 \\ 0.3 & 0.4 & \text { n.d. } \\ \text { n.d. } & \text { n.d. } & \text { n.d. }\end{array}$


Table 6

$\begin{array}{llll}\text { Cation(coord\#) } & \alpha, \AA^{3} & \Delta=\left[\alpha_{\text {(light ion) }-} \alpha_{\text {(heavy ion })}\right] / \alpha_{\text {(light ion) }} \\ \mathrm{Y}^{3+}(\mathrm{VI}) & 2.12 & \Delta \mathrm{Y} \text {-Dy(VI) } & -0.0896 \\ \mathrm{Y}^{3+}(\mathrm{VIII}) & 1.844 & \Delta \mathrm{Y} \text {-Dy(VIII) } & -0.1236 \\ \mathrm{Zr}^{4+} & 2.023 & \Delta \mathrm{Y} \text {-Ho(VI) } & -0.0566 \\ \mathrm{Nb}^{5+} & 3.10 & \Delta \mathrm{Y}-\mathrm{Ho}(\mathrm{VIII}) & -0.0906 \\ \mathrm{Dy}^{3+}(\mathrm{VI}) & 2.31 & \Delta \mathrm{Y}-\mathrm{Er}(\mathrm{VI}) & -0.0283 \\ \mathrm{Dy}^{3+}(\mathrm{VIII}) & 2.072 & \Delta \mathrm{Y}-\mathrm{Er}(\mathrm{VIII}) & -0.0553 \\ \mathrm{Ho}^{3+}(\mathrm{VI}) & 2.24 & \Delta \mathrm{Zr}-\mathrm{Hf} & 0.0657 \\ \mathrm{Ho}^{3+}(\mathrm{VIII}) & 2.011 & \Delta \mathrm{Nb}-\mathrm{Ta} & 0.0903 \\ \mathrm{Er}^{3+}(\mathrm{VI}) & 2.18 & & \\ \mathrm{Er}^{3+}(\mathrm{VIII}) & 1.946 & & \\ \mathrm{Hf}^{4+} & 1.89 & & \\ \mathrm{Ta}^{5+} & 2.82 & \end{array}$

